San Jose State University

SJSU ScholarWorks

Master's Theses

Master's Theses and Graduate Research

Fall 2018

\title{
College Students Experiencing Food Insecurity at San Jose State University
}

Elizabeth Agramont-Justiniano

San Jose State University

Follow this and additional works at: https://scholarworks.sjsu.edu/etd_theses

\section{Recommended Citation}

Agramont-Justiniano, Elizabeth, "College Students Experiencing Food Insecurity at San Jose State University" (2018). Master's Theses. 4959.

DOI: https://doi.org/10.31979/etd.5p8d-4c27

https://scholarworks.sjsu.edu/etd_theses/4959

This Thesis is brought to you for free and open access by the Master's Theses and Graduate Research at SJSU ScholarWorks. It has been accepted for inclusion in Master's Theses by an authorized administrator of SJSU ScholarWorks. For more information, please contact scholarworks@sjsu.edu. 


\title{
COLLEGE STUDENTS EXPERIENCING FOOD INSECURITY AT SAN JOSÉ STATE UNIVERSITY
}

\author{
A Thesis \\ Presented to \\ The Faculty of the Department of Sociology and Interdisciplinary Social Sciences \\ San José State University \\ In Partial Fulfillment \\ of the Requirements for the Degree \\ Master of Arts
}

Elizabeth Agramont-Justiniano

December 2018 
(C) 2018

Elizabeth Agramont-Justiniano

ALL RIGHTS RESERVED 
The Designated Thesis Committee Approves the Thesis Titled

COLLEGE STUDENTS EXPERIENCING FOOD INSECURITY AT SAN JOSÉ STATE UNIVERSITY

by

Elizabeth Agramont-Justiniano

APPROVED FOR THE DEPARTMENT OF SOCIOLOGY

SAN JOSÉ STATE UNIVERSITY

December 2018

William Armaline, PhD

Natalie Boero, PhD

Scott Myers-Lipton, PhD
Department of Sociology and Interdisciplinary Social Sciences

Department of Sociology and Interdisciplinary Social Sciences Department of Sociology and Interdisciplinary Social Sciences 


\title{
ABSTRACT \\ COLLEGE STUDENTS EXPERIENCING FOOD INSECURITY AT SAN JOSÉ STATE UNIVERSITY
}

\author{
by Elizabeth Agramont-Justiniano
}

The purpose of this research was twofold: to learn more about how students at San José State University experience food insecurity and to learn how food insecurity is addressed by this public university given the rise and prevalence of neoliberalism in higher education. I conducted three focus groups to better understand how students define food insecurity and what their experiences with food insecurity at college are like. I also conducted eight in-depth, semi-structured interviews with students to explore further how it feels to experience food insecurity at San José State University. The overwhelming majority of students I interviewed experienced stress due to not knowing when their next meal would be. Students also expressed tremendous guilt and shame because of their inability to afford food. The ongoing struggle to fully address and meet the needs of students is influenced by neoliberal policies, which promote short-term profit as a primary goal. Measures by the college and university should be made to ensure that student needs are fully understood and prioritized to promote student academic success and well-being. 


\section{ACKNOWLEDGEMENTS}

Thanks to my professors Armaline, Boero, and Myers-Lipton for consistently providing me with the feedback and guidance needed to complete this project. Without their tremendous support, this work would not be possible.

Thank you to the brave students who shared their personal stories and struggle each day, combating shame and embarrassment to get the food that they need. Thank you for helping spread the word about the resources available to your friends and fellow classmates.

Thank you to the members of the University who have worked tirelessly to secure further resources for the thousands of students experiencing food insecurity. 


\section{TABLE OF CONTENTS}

List of Tables.................................................................... vii

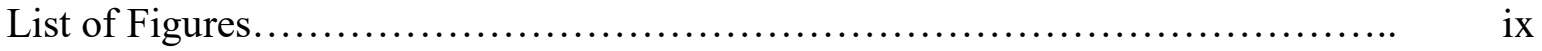

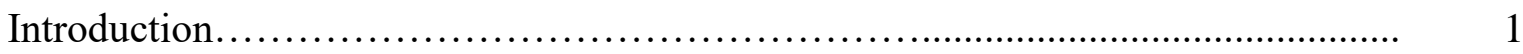

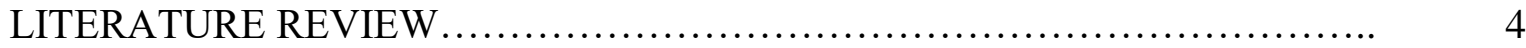

Food Insecurity Among College Students................................ 4

First-Generation College Students and College Costs........................... 7

Poverty, Race/Ethnicity, and Gender.................................. 12

History of Privatization in Education.................................... 17

SAN JOSE STATE UNIVERSITY'S APPROACH TO FOOD INSECURITY ...... 24

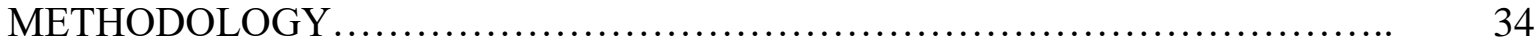

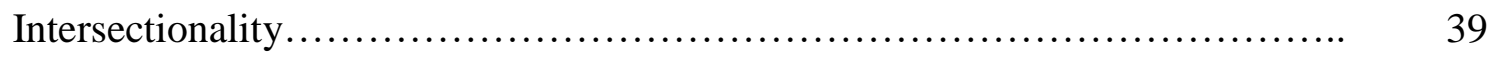

Institutions of Power................................................. 40

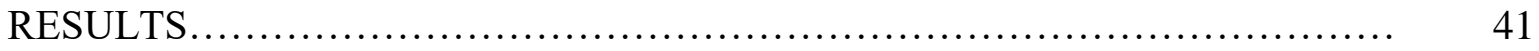

What is Food Insecurity? ........................................................................

Lack of Health and Mental Well-Being..................................... 44

Growing up in Poverty................................................ 50

Coping Strategies........................................................ 58

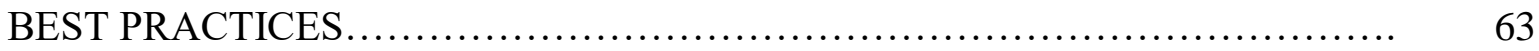

Central Food Pantry .................................................. 63

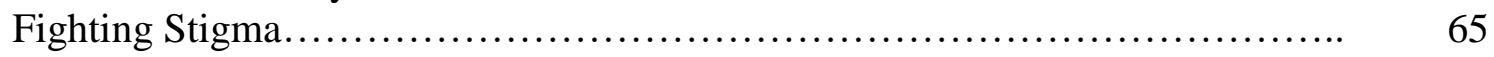

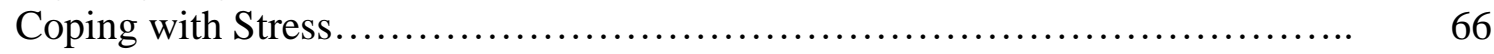

Community Garden ........................................................ 68

FOOD RESOURCE LEGISLATIVE POLICIES ON CAMPUS .................... 70

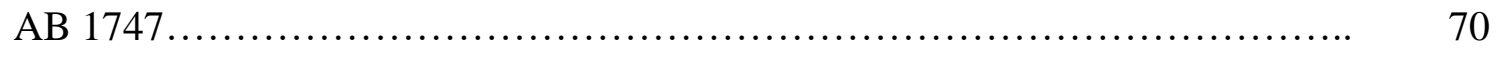

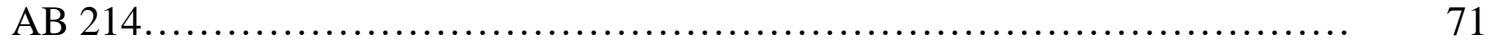

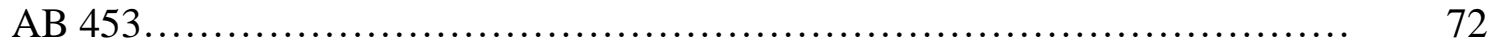

DISCUSSION AND CONCLUSION ....................................... 
BIBLIOGRAPHY .................................................. 77

Appendix A........................................................ 85

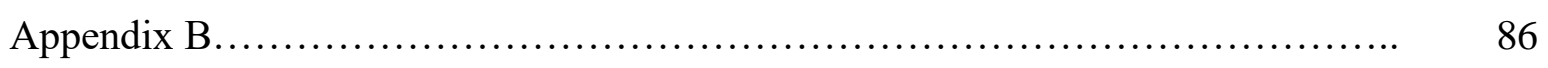

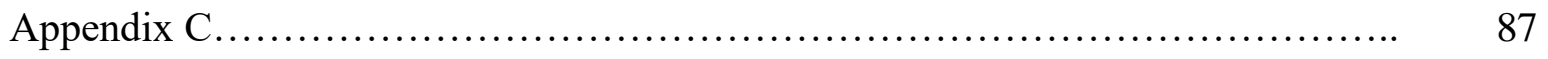




\section{LIST OF TABLES}

Table 1. Participants by race and gender.......................................

Table 2. Participants Food Security Status, Living Arrangements,

Student Status, and Working Situation................................. 30 


\section{LIST OF FIGURES}

Figure 1. San José State University Demographics.............................. 72 


\section{INTRODUCTION}

Sitting in class, Justine is tired, hungry, and having difficulty concentrating on class material as she contemplates when and where her next meal is coming from. "Yeah I agree with what was said because you know being in classes is really difficult when your mind is always on it (food). You can try all you want to stop thinking about it, but your mind goes back to it in like five minutes," she describes. Because she does not have enough to eat, Justine is stressed and unable to concentrate in class. She is experiencing food insecurity. Food insecurity, as defined by the United States Department of Agriculture (USDA) ${ }^{1}$, "refers to the social and economic problem of a lack of food due

${ }^{1}$ The USDA measures both food security and food insecurity and utilizes the following labels: high food security, marginal food security, low food security, and very low food security. The USDA has developed a survey of 18 questions on food consumption, food spending, and government assistance programs. These questions are sent out along with the Current Population Survey (CPS), which is a nationally representative survey conducted by the Census Bureau for the Bureau of Labor and Statistics. This survey is sent out every December, and approximately 45,000 households respond (USDA Economic Research Service Food Insecurity in the U.S. 2017). In 2008, there were approximately 49.1 million households in the U.S. that were experiencing food insecurity (Holben 2010). Out of this population, 15.8 million were children, and 33.3 million were adults (Indiana's Emergency Food Resource Network 2013). Therefore, approximately $16 \%$ of Americans are food insecure. These statistics seem to correlate with the 47 million people who live in poverty in the U.S. (Myers-Lipton 2014).

Although there is a large portion of people living outside of poverty who are still food insecure (Feeding America Poverty and Hunger Fact Sheet 2017). According to Feeding America, $61 \%$ of people living in poverty experience food insecurity (Feeding America Hunger and Poverty Fact Sheet 2017). The number of people in poverty and facing food insecurity is staggering, considering that the U.S. is the wealthiest nation in the world (Melendez 2012). Furthermore, the U.S. wastes a tremendous amount of food every year. According to the USDA, the United States wastes up to a third of its food supply, which accounts for 133 billion pounds of food each year (USDA 2015). The fact that many millions of people are food insecure in the U.S. is not due to a lack of resources but rather the distribution of these resources. Money that could be used in the public sector for food banks, education, and healthcare goes to private entities, namely multibillion-dollar corporations. Private corporations are not required to pay large taxes, receive large tax write-offs, and create offshore tax havens to keep their money overseas. Private profit has become a top priority above people's everyday survival needs. 
to resource or other constraints" (National Academies Press 2006). There are currently no national statistics on how many college students living in the U.S. are food insecure. However, available data suggest that college students may be more likely to experience food insecurity than the general population ${ }^{2}$.

Justine attends San José State University (SJSU), which is a part of the California State University (CSU) system. A study released by the CSU system in January 2016 found that one in five students are impacted by food insecurity (Crutchfield 2016). There are approximately 478,640 students in the CSU system making it the largest state university system in the country. Ergo, more than 95,000 students may be struggling with food insecurity. Rates of food insecurity at SJSU may be even higher than the state average. According to a survey done at SJSU in 2015, 1 in 3 students reported that it was often or sometimes true that they would skip meals due to not being able to afford food (Student Food Access Survey 2014: 8). In light of these data, many colleges and universities have dedicated resources, staff, and funding to address this problem and assist their students.

To better understand food insecurity among college students in the U.S., specifically those attending SJSU, my research addresses two central questions: (1) How do SJSU students experience and define food insecurity? (2) How does SJSU define and address food insecurity, and to what extent is the private sector involved in SJSU's approach toward addressing food insecurity? This research intends to provide insight into how

\footnotetext{
${ }^{2}$ In 2016, the national average for food insecurity in the United States was $12.3 \%$ (ColemanJensen, Rabbitt, Gregory, and Singh 2017).
} 
college students may be affected by food insecurity and the meanings they associate with it. Additionally, this research intends to outline how SJSU responded to food insecurity among its college students.

Three substantive areas of sociological literature inform the research questions posed here: 1) higher education, 2) poverty, and 3) food insecurity. In order to best understand the context of collegiate food insecurity, we must examine the influence of higher education, the impact of poverty, and the effect of food insecurity on the lives of college students. Sociological research on higher education provides data on low-income and first-generation college students, but not much research exists on first-generation and low-income students who are food insecure. Likewise, poverty studies have primarily focused on single mothers and children who are poor, not college students (Gortmaker 1979; Edin and Lein 1996; Christopher, England, Smeeding, and Phillips 2002; Rainwater and Smeeding 2003 \& Edin and Reed 2005). Until recently, food insecurity has not included college students as an area of focus (Cady 2014; Goldrick-Rab, Broton, and Eisenberg 2015; Crutchfield, 2016 \& Broton; Goldrick-Rab 2016).

First, I examine food insecurity at colleges and universities as a social problem through the lens of poverty, food insecurity, and higher education. Second, I detail my methodology. Third, I discuss my findings and identify emergent themes in my data. Finally, I conclude with a discussion of the implications of my findings and I outline best practices and policies for colleges and universities seeking effective responses to food insecurity. 


\section{LITERATURE REVIEW}

There are many aspects of students' lives to take into consideration when examining food insecurity. First, I examine earlier studies done on college students and food insecurity. Then, I discuss look at first-generation college students, the increase in college tuition, and its impact on college students. Next, I review key literature on poverty, racial demographics, and single mothers . Finally, I provide key definitions and a summary of the history of privatization in higher education.

\section{Food Insecurity Among College Students}

My research investigates the experiences of SJSU students with regards to food insecurity. Therefore, it is important to understand the sociological research done on college students experiencing food insecurity. During the 1980s, food insecurity research was limited to quantitative studies attempting to define the scope of this issue as part of a broader effort of sociologists to identify the poor in America (Rainwater and Smeeding 2003). In recent years, studies like that of Goldrick-Rab (2015) at the Wisconsin HOPE Lab include in-depth interviews with students. One student in this study revealed that she was on her own since the age of 19 , living paycheck to paycheck, and unable to receive food stamps from the government even though she were struggling. Another student explains the difficulty of concentrating in class while being food insecure (Goldrick-Rab 2015). Not many qualitative studies explicitly ask students about their experience with food insecurity. Therefore, like the above study, the focus of this research is to further examine students' experiences with food insecurity as well as the University's response to the problem. 
Until recently, food insecurity on college campuses remained invisible (Goldrick-Rab 2015). Part of the reason it has taken so long to recognize food insecurity among college students is that poverty and food insecurity studies primarily focused on single mothers with children (Gortmaker 1979; Edin and Lein 1996; Christopher, England, Smeeding and Phillips 2002; Rainwater and Smeeding 2003 \& Edin and Reed 2005). Attending college is a tremendous opportunity, and yet, due to high cost of living, college expenses, and an increase in the number of college students coming from low-income backgrounds, food insecurity has become more common. Colleges and universities are beginning to respond to this crisis by providing their students with free and low-cost food resources (Goldrick-Rab, Broton, and Eisenberg 2015).

Though there is relatively little sociological research on the contemporary experience of food insecurity among college students, recent investigative journalism ${ }^{3}$ and internal studies illustrate the prevalence of food insecurity in the CSU system. In a 2015 study conducted by the CSU system, 1 in 5 students reported that they experienced food insecurity (Crutchfield 2016). At SJSU, 1 in 3 students indicated that it was often or sometimes true that they would skip meals due to not being able to afford food (Student Food Access Survey 2014). Additionally, a staggering 1 in 5 students reported that it was often or sometimes true that they would go entire days without eating due to not being able to afford food (Student Food Access Survey 2014). According to the "Feeding

\footnotetext{
${ }^{3}$ More and more stories of students who are unable to eating are being revealed across the country and on-campus food pantries have emerged as an attempt to address this problem.
} 
America 2014 Hunger in America" report, ten percent of the 46.5 million food bank clients are students, two million of whom attend school full-time (Feeding America 2014). One third of full-time students reported having to choose between food and covering educational expenses. Out of all those attending college, approximately half had to choose between food and expenses such as tuition, books, supplies, and rent (Feeding America 2014). College costs have increased over the last 25 years by $400 \%$, while the median household income has only increased by $150 \%$ (Orozco and Cauthen 2009). Many low-income students attend college in order to improve their own and potentially their family's life circumstances by improving their opportunities and hopefully gaining some semblance of upward social mobility (Goldrick-Rab, Broton, and Brunjes-Colo 2016).

Considering the fact that such a large percentage of the college population is experiencing food insecurity, this research aims to examine the ways that one university has responded to this widespread problem. The research regarding food insecurity at the college level tends to focus exclusively on economic resources. However, many other aspects of students' lives increase their risk of experiencing food insecurity and influence how they practice coping strategies to manage their food insecurity. College students are unique populations with respect to food insecurity because they must balance their academic, professional, and familial responsibilities, all of which impact their approach to food insecurity. It is important to note that the food insecurity experienced on college campuses in the CSU system, and at SJSU specifically, are much higher than the national average of food insecurity found in $14.5 \%$ of households (Feeding America, 2015). And 
although food insecurity can conceivably affect students of all racial and ethnic backgrounds, certain demographic groups of students experience it at disproportionate rates, including students of color and low-income students ${ }^{4}$. Additional resources are needed to adequately provide support for these communities, which often translates into spending additional funds. Yet, privatization emphasizes diverting these funds to be used to produce short-term profit for investors.

\section{First-Generation College Students and College Costs}

A focus on poverty among first-generation college students is a relatively recent phenomenon. Much sociological research on poverty focused on families, children, and single mothers (Gortmaker 1979; Edin and Lein 1996; Christopher et al. 2002; Rainwater and Smeeding 2003 \& Edin and Reed 2005), despite the fact that many first-generation students experience intergenerational poverty. Many public college students are firstgeneration (National Center for Public Policy and Higher Education 2011). According to the Higher Education Act: “The term 'first-generation college student' means- (A) An individual both of whose parents did not complete a baccalaureate degree; or (B) In the case of any individual who regularly resided with and received support from only one parent, an individual whose only such parent did not complete a baccalaureate degree"

\footnotetext{
${ }^{4}$ In a study conducted by the USDA in 2009 there were certain factors, which increase likelihood of the prevalence of food insecurity. Blacks and Latinos had higher prevalence of food insecurity as did those who were categorized as $185 \%$ below the federal poverty line. Additionally, people living in urban and rural areas were more likely to experience food insecurity than those living in the suburbs. In households with food insecure children, two-thirds had one or more full time workers. Rates for food insecurity were higher among those who were unemployed or disabled. Food insecurity was also ten times more prevalent in households in which no adult had completed high school (USDA 2009).
} 
(Higher Education Act 1965). For the purpose of this research, "first-generation college students" refers to students who are the first in their families to attend college. Part of the reason why these students are the first in their families to attend college is because they have experienced intergenerational poverty, which increased the obstacles for them to attend colleges and universities. Many people living in poverty experience food insecurity, including college students. College students in particular are unable to afford food because of other living expenses (Cady 2014 \& Goldrick-Rab, Broton, and Eisenberg 2016). Additionally, this research asks students questions regarding whether their family is aware that they experience food insecurity.

Students of color, who are often the first in their family to go to college and are low income, may be struggling to find time to study and work (Goldrick-Rab 2015). Studying would guarantee their academic success, while working provides them with the economic support needed to survive. Many first-generation students come from low-income backgrounds and consider public colleges and universities more affordable for themselves and their families than private colleges and universities (U.S. News, Powell, 7/31/2017).

First-generation college students of color from working class and poor backgrounds face challenges their middle class and/or white peers do not. First-generation students often have responsibilities that other students do not (Benmayor 2002; Aronson 2008; Wang 2014; Rondini 2016). For example, first-generation students may work long hours to contribute to family expenses and tuition costs, cutting into the time they have to study. 
First-generation students also face negative stigma associated with race and/or class (Zalaquett 2005). Many first-generation students and families do not want to be seen as a burden to society or deemed as trying to take advantage of the system. The fear of stigmatization is an additional obstacle to first-generation students seeking out assistance, particularly for food insecurity. Students may be hesitant to ask for help for fear of being looked down upon (Wheeler 2016).

First-generation students are more likely to enroll in 2-year than 4-year colleges (Aronson 2008). This trend could be because community colleges are more affordable than four-year colleges, allowing students to continue to work and save up for school if they intend on transferring. First-generation students as high school students may not be provided with the appropriate resources or assistance by their teachers and counselors and are therefore pushed toward attending community college due to institutional racism, segregation, and class discrimination (Desmond and Lopez Turley 2009). When devising means of addressing problems like food insecurity and other issues faced by these students, it is crucial to consider that first-generation students may have experienced discrimination or the sense that their school administration does not care about their academic success.

Many unique challenges confront first-generation students. They may feel additional responsibility and pressure to make their family proud because of the life struggles that their parents and family have experienced (Zalaquett 2005; Wang 2014; Rodini 2016). First-generation students may also feel tremendous guilt about attending college because members of their family have not experienced the same academic opportunities and 
achievements (Covarrubias, Romero, and Trivelli 2014). Furthermore, first-generation students feel additional pressure to pursue the major and course of study discussed by their family (Wheeler 2016). First-generation students often face difficulties navigating the college system and do not have a clear understanding of all the resources provided at college such as a career services center or counseling and psychological center (Wheeler 2016).

Another challenge for first-generation and low-income students is skyrocketing college tuition. Tuition prices are rising faster than inflation or need-based financial aid (Goldrick-Rab, Broton, Schwarz, and Scafidi 2003; Wellman; Dannenberg and Voight 2013; Houle 2013). The rising cost of tuition has forced many students to seek assistance from their parents, work, take out loans, or hold off on attending college altogether (Dannenberg and Voight 2013; Houle 2013; Delaney 2014). Paying for college is extremely difficult for students struggling to escape poverty and who may not be able to rely on their family for financial support (Dannenberg and Voight 2013). In fact, these students may have families that rely on them to help out financially. In a study conducted by the Wisconsin HOPE Lab, students indicated all of the ways that they provided assistance to their families. Sixty-seven percent of students of color contributed more money to their family compared to $52 \%$ of white students. Students provided financial assistance to their families for the following: transportation (23\%), food (38\%), housing $(16 \%)$, and other expenses $(34 \%)^{5}$. Thus, students from a lower socioeconomic status

\footnotetext{
${ }^{5}$ This study also asked students about the other ways they contributed to their family by providing: emotional support (90\%), share car/rides (54\%), housing (22\%), and taking care of a child or disabled adult (37\%) (Wisconsin HOPE Lab Data Brief 2016).
} 
who are working to support either themselves or their family may find themselves food insecure. Taking out loans is also risky because that forces students into debt without the guarantee that their degree will grant them employment satisfactory to pay off their debt; the national debt is around $\$ 1.3$ trillion (New York Federal Reserve Quarterly on Household Debt and Credit 2016). Students who are undocumented face an increased risk: they do not qualify for federal loans and therefore must pay for all costs upfront.

Student unemployment is strongly connected to food insecurity. One study of students who utilized an on-campus food pantry revealed that $45.5 \%$ of students utilizing the Food Pantry were unemployed, along with the $23 \%$ of students who were employed but still could not afford food (Twil, Bergdahl, and Fensler 2016). Other students had trouble budgeting and ran out of money, did not receive enough financial aid to cover costs, or were waiting for food stamp benefits (Twil et al. 2016). Students who were most likely to utilize the food pantry were Pell grant recipients, unemployed, Black, and live off-campus. ${ }^{6}$ Black women were overrepresented in food pantry usage, which is consistent with their representation among those living in poverty (Twil et al. 2016). Public funding available to students is insufficient to meet the financial costs of higher education. Current funding is still insufficient to meet the existing need. To keep up with the need, more money needs to be distributed to the public welfare state instead of the private sector.

\footnotetext{
${ }^{6}$ Pell grant recipients (57\%), unemployed (67\%), Black (50\%), and live off-campus (53\%).
} 
In the City University of New York (CUNY) system, Blacks and Latinos were 1.5 times more likely to be food insecure than Whites and Asians. At CUNY University, 26\% of students made less than $\$ 20,000$ a year and were also more likely to be food insecure. Financially independent students were 1.6 times more likely to be food insecure than dependent students. Furthermore, $63 \%$ of students receiving Food Stamps were food insecure, indicating that the money allocated for Food Stamps is not sufficient (Freudenberg, Manzo, Jones, Kwan, Tsui, and Gagnon 2011). Most students who grow up in poverty continue to have the same financial constraints while in college (GoldrickRab, Broton, and Brunjes Colo 2016). Students from low socioeconomic statuses must allocate large portions of their income to pay for college. For dependent students, this amounts to $40 \%$ of their income (Goldrick-Rab et al. 2016). However, independent students must pay more than $100 \%$ of their income to pursue a 2year degree (Goldrick-Rab et al.) Several factors contribute to whether a student is food insecure, which stem from economic, gender, and racial disparities. Therefore, in both identifying the problem and developing solutions, food insecurity should be understood in a racial, gendered, and class context.

Poverty, Race/Ethnicity, and Gender

In this section I outline the ways students from certain demographics may be disproportionately affected by food insecurity. Demographic categories such as race, class, and gender are important to consider when studying food insecurity because SJSU has a very diverse population of students: $41.2 \%$ are Asian, $26 \%$ are Latinx, $19.4 \%$ are White, $9.8 \%$ are Other, 3.1\% are Black, .4\% are Pacific Islander, and .1\% are American 
Indian (See Appendix A). SJSU is 51.1\% male and $48.9 \%$ female. For the most recent semester, fall 2017 , total enrollment was $34,686^{7} .23,120$ students, or $67 \%$, received some form of financial aid. And 17,248 students, 50\%, received Pell grants, which are awarded to low-income students. Therefore, in conducting this research, it is important to examine how the role of race, poverty, and gender may impact these student participants and the greater SJSU student population. For instance, students coming from low-income backgrounds may not have parents to assist them in paying for tuition and thus must pay their own tuition. Additionally, students coming from certain racial/ethnic groups could be disproportionately disadvantaged in terms of navigating the college/university system. Students growing up with single-mothers may be more likely to come from low-income backgrounds and might be struggling as well.

In 2016, there were 40.6 million people living in poverty in the United States (Feeding America 2017). According to Feeding America, in 2015, 47 million people residing in the United States were experiencing food insecurity (2015). People of color and women are disproportionately affected by poverty and are more susceptible to experiencing food insecurity. Poverty research focused on defining characteristics of people living in poverty such as race and gender (Christopher et al. 2002). Due to a series of historically and systematically racist, exploitative, and oppressive practices, people of color, particularly Blacks, Latinos, Native Americans, and

\footnotetext{
${ }^{7}$ Office of Financial Aid
} 
South Asians and Pacific Islanders are disproportionately represented in poverty (Cabaniss and Fuller 2005).

Asian-Americans for instance, are among those sometimes constructed as "model minorities" that either do not face financial hardship or do not speak of their hardship (Gold and Kibria 1993; Espiritu 2006; Ngo and Lee 2007; Johnson and Betsinger 2009). However, it is important to understand that the people identified in the ethno-racial concept of "Asian” represent many different countries and cultures. They have varying experiences immigrating into the U.S. based on their time of arrival. The socio-political context of when they arrived shaped how they were perceived and treated while living in the United States (Kibria 1993; Um 2003; Espiritu 2006; Ngo and Lee 2007). Thus, many recent Asian immigrants experience higher rates of poverty than Whites (Takei and Sakamoto 2011).

A vast literature documents how women-more specifically, single mothers—-are living in poverty (Gortmaker 1979; Edin and Lein 1996; Christopher et al. 2002; Rainwater and Smeeding 2003; Edin and Reed 2005). Women, especially women of color, have long been overrepresented among the poor. (Canabiss and Fuller 2005 and Myers-Lipton 2014). Studies show that women are not paid as much as men, even when controlling for education and years of experience. Additionally, women are more likely to be single mothers and raise their children with little or no financial support from their partners. Having a lack of financial and child rearing support makes it difficult for mothers to further their education, which would subsequently increase their earning potential and chances of escaping poverty, contributing to what Diana M. Pearce 
identifies as the feminization of poverty (1978). The feminization of poverty refers to how women make up the majority of those represented in poverty. The feminization of poverty will be critical to examine when looking at students who may be raised by single mothers.

Services and resources are available to people facing financial difficulties. However, there has been a long, ongoing debate regarding who should receive financial resources such as welfare. This debate has shaped how people living in poverty are viewed by society (Abramovitz 1988; Piven and Cloward 1993; Neubeck and Cazenave 2001). Welfare or public/governmental assistance has been given to people in need of economic support, most notably after the Great Depression, in the form of Social Security and a variety of programs provided under The New Deal ${ }^{8}$ (Abramovitz 1988). There has been a debate over who should receive these resources and assistance. Policy surrounding distribution of public goods has been centered on social beliefs and values about who is deserving or undeserving (Abramovitz 1988; Piven and Cloward 1993; Neubeck; Cazenave 2001;). The controversy over who is deserving or undeserving with regards to welfare is a prominent example of this debate.

Welfare has become both racialized and stigmatized (Neubeck and Cazenave 2001). Women of color, specifically Black women with children, have been targeted and labeled as "welfare queens". "Welfare queen" is a term coined in the Reagan era that ascribes negative characteristics to low-income women of color including laziness, greediness,

\footnotetext{
${ }^{8}$ The Federal Emergency Relief Act, Public Works Administration, Civil Works Administration, and the Civilian Conservation Corps.
} 
aggression, poverty, and hostility. People living in poverty and low-income people of color raising a family experience guilt and shame because of these negative portrayals. The rhetoric and discriminatory selection of people eligible to receive benefits have made people feel ashamed about receiving and utilizing the resources they need to survive.

Funding for welfare and other governmental assistance programs is constantly threatened. SNAP (Supplemental Nutritional Assistance Program), Medicaid, and TANF (Temporary Assistance for Needy Families) may lose several hundreds of billions of dollars over the next decade (NY Times, Alcindor, 5/22/2017). Many conservative politicians argue that people need to be independent and that the government plays too strong a role in people's lives (The Week, Paul Waldman, 9/21/2017). For instance, in his inaugural address, Ronald Reagan stated: "In this present time, government is not the solution to our problem; government is the problem" (The American Heritage Project, 2018). This argument is used time and time again to decrease funding available to assist those most in need by both the Republican and Democratic Party ${ }^{9}$. (CNN Money, Tami Luhby, 8/9/2012).

Therefore, the resources provided by the government are insufficient. For instance, the poverty line way in which the federal poverty line is calculated has not changed since 1963. The poverty threshold is calculated by the U.S. Census Bureau for Labor and Statistics and is three times the amount needed for an economy food plan (Institute for

\footnotetext{
${ }^{9}$ Welfare funding, Temporary Assistance to Needy Families (TANF) decreased. http://money.cnn.com/2012/08/09/news/economy/welfare-reform/index.htm
} 
Research on Poverty, 2016). Because of the government's failure to consider the increase in cost of living and wage stagnation as well as the increase of part-time, low-wage, no benefit or insurance jobs, people are receiving inadequate resources and left to fend for themselves, unable to escape poverty. Thus, low-income families are often unable to fully provide for their children financially even if they are receiving government funding. People are likely to remain in poverty because negative portrayals spread by politicians, pop culture, and the media fail to invoke widespread concern for their well-being. These negative portrayals are spread at the benefit of the government and large corporations that are pushing neoliberal policies, which prioritize profit over people's well-being —an additional cost that they would rather capitalize on and invest. And so, due to neoliberal policies and practices, people continue to be viewed as undeserving of support, and consequentially, funding for these vital and lifesaving resources continues to decline. A precedent has been created for low-income people, communities of color, and families led by women to not receive the support they need, which gives future generations-even in college - a higher likelihood of not receiving requisite financial resources, possibly resulting in food insecurity.

\section{History of Privatization in Education}

In public institutions of higher education, the private sector has had a tremendous effect. This impact has lead me to explore the extent to which the private sector is involved in SJSU's approach to addressing food insecurity. Privatization refers to taking 
social and public goods and placing ownership and control in the private sector, which is a fundamental tool of neoliberalism (Armaline, Glasberg, and Purkayastha 2015:123). One of the major ways neoliberalism manifests is through "privatization of public goods and services, decreased regulation on trade, loosening of capital and labor controls by the state, and the allowance of foreign direct investment" (Saltman 2006:345). In higher education, privatization can be characterized as an increased usage of taxpayer money for voucher programs, charter schools, the presence of commercialized products and advertisements, online classes, and colleges (Saltman 2006:340). Privatization of higher education can assume other forms as well. This is outlined by Giroux: "Corporate leaders now are hired as university presidents, the shrinking ranks of tenure-line faculty are outsourced to contract labor, students are treated as customers, and learning is all too often defined in instrumental terms while critical knowledge is relegated to the dustbin of an impoverished and underfunded liberal arts" (2010:186). Giroux identifies a critical point of contention with how public colleges and universities are operated and managed as businesses where the primary goal is no longer educating students and valuing faculty but rather ensuring that capitalist policies are understood and enforced from the top down.

The privatization of public higher education has expanded since the 1980s. The question of both its effectiveness and prevalence has been explored by several researchers (Altbach and Levy 2005; Torche 2005; Levy and Zumeta 2011; Levy 2013; Buckner 2017). Levy argues that in the United States, it is rare for a public institution to become private, but there are many public institutions that adopt activities and values 
characteristic of private institutions (2013). Researchers question whether student needs can be fully addressed with the presence of private interest (Spring 1972; Overtz 1996; Saltman 2006). They argue that by public colleges and universities engaging in privatization, key opportunities to secure resources to meet student needs are not met (Spring 1972; Overtz 1996; Saltman 2006). The practice of privatization in institutions of higher education is important to discuss because colleges and universities are obligated by law to serve their students. Therefore, more attention should be on whether colleges are able to successfully meet student needs, especially food insecurity, considering its connection to a student's academic success.

Saltman (2006) points out that supporters of neoliberalism believe that the private market is able to process and deliver public resources and services more efficiently (345). He states:

[A]dvocates of privatizing public schools often claim that public schooling is a "monopoly" that public schools have "failed," that schools must "compete" to be more "efficient" while parents ought to be allowed a "choice" of schools from multiple educational providers as if education were like any other consumable commodity (Saltman 2006:344).

However, the idea that the private sector can outperform the public sector is simply not true. During the 1980s and 1990s there was an increase in for-profit education companies that claimed that they could run public schools more cost effectively and efficiently than the government (Saltman 2006:342). Saltman criticizes this assertion by stating, “. . .[H]ow could an organization drain financial resources to profit investors and still maintain the same quality that the organization had with the resources that could be paying for more teachers, books, supplies, and upkeep?” (2006:342). Financial 
institutions, by law, are only beholden to their shareholders - those with a financial investment in the company — and not its stakeholders: students trying to experience a quality education. Therefore, a financial institution managing a for-profit institution has no obligation to upholding academic values and standards.

The narrative surrounding performance is used by supporters of neoliberalism to present its services as a solution to a social problem. Supporters of neoliberalism uphold the values and practices of capitalism while simultaneously distracting the public from the fact that neoliberal practices are responsible for creating these problems in the first place. "Shock Doctrine" is a theory established by Naomi Klein (2014) to better describe the intricate and essential role that crisis plays in executing and extending neoliberal policies and practices. The essential premise of the "shock doctrine" theory is that during a time of crisis (environmental, financial, national, etc.), capitalists will try to either pass or prohibit policies and laws in order to maximize short-term profit (Klein 2014:6). Advocates of neoliberal policy understand that during times of crisis, people are in shock and uncertain about what to do. Therefore, capitalists push and promote their own services, ideology, and agenda as the answer to the public's problems knowing that people are in desperate need of a solution (Klein 2014).

In order to fund these initiatives, capitalists do not utilize their own funds but rather engage in austerity tactics by utilizing money from state taxes or various fees in order to avoid cutting into their profit revenue. This same concept of austerity can be applied at the university level: 
In order to free up the capital necessary to underwrite entrepreneurial projects, the universities have introduced a process of selective austerity to reappropriate funds from programmes that are 'unprofitable' or resistant to commercialization. Tuition and fee increases, reorganization of the way the endowment is spent and invested, and a change in the way austerity is imposed have become commonplace (Ovetz 1996:126).

Through austerity measures, money is taken from academic departments and campus organizations that produce very little or no profit and are then given to programs and services that generate a short-term profit. In order for capitalism to function, it relies on a model of endless growth, which is only possible when markets are diversified and other costs are minimized. Consequently, austerity and privatization measures cause essential student resources to be underfunded. Hence, these programs and departments are seen as ineffective, when in reality, they lack the proper financial support and university acknowledgement required to be successful. These methodologies reiterate the notion that only capitalist solutions are truly effective, yet this is not true. Also, these practices lead to an inordinate focus on students facing immediate economic emergencies rather than the greater number of students experiencing need and crisis due to systemic stressors such as food insecurity.

Klein coins the term "people shock" to describe times when people come together and demand that more socially conscious and people-oriented programs and policies be implemented to help alleviate a given problem (Klein 2014:8). Elaborating on this concept, Klein refers to the housing and financial crisis of 2008 as a key moment in which, instead of bailing out the big banks, we could have demanded for more quality jobs that both recognize the rights of people to live as well as create a more sustainable 
environment so that life can persist and resources are not exploited to depletion or extinction (Klein 2014:105-107). Nevertheless, Klein points out that privatization practices are on the rise globally, despite the precarious situation it is placing the entire planet and all its species.

A defining moment for privatization in public education was the signing into law of the "No Child Left Behind" (NCLB) policies by the George W. Bush administration. Through NCLB billions of dollars went to starting up charter schools as well as expanding for profit testing and textbook companies (Saltman 2006:341). As stated previously, the for-profit charter school movement has largely been unsuccessful in providing quality education, which should come as no surprise since its main objective is increasing their shareholders' dividends. But, unlike the stock market, institutions of higher education have obligations to their students. When profits are the primary driving force in an educational setting then "At stake in the struggle for public education is the value of critical and public education as a foundation for an engaged citizenry and a substantive democracy" (Saltman 2006:340). If institutions of education are no longer centered on students and learning, then having informed citizens shaping democracy is put at risk.

On August 23rd, 1971, Lewis Powell, a corporate lawyer, sent a memo to the U.S. Chamber of Commerce stating that colleges and universities were becoming too Democratic and that this was an attack on big businesses and the free market enterprise as a whole (Powell, 1971:12-15). He urged businesses to unite and fight back, which they did with a force mobilizing lobbyists and busting unions. Business saw university 
education as a threat to capitalism. Public schools then and now are being privatized in order to " $[\mathrm{M}]$ eet the needs of the corporate state and consequently, to protect the interests of the ruling elite and the technological machine" (Spring 1972:2). By adhering to privatization: "Faculty in this view are just another cheap army of reserve labor, a force to eagerly exploit in order to increase the bottom line while disregarding the rights of academic labor and the quality of education that students deserve." (Giroux 2010:185). Engaging in practices such as austerity and privatization de-prioritize the two essential stakeholders (students and teachers) within the educational system. Students' needs are not being properly funded because they are an expense that does not led to an immediate short-term profit for shareholders. 


\section{SAN JOSÉ STATE UNIVERSITY'S APPROACH TO FOOD INSECURITY}

To better understand SJSU students' experiences with food insecurity, it is important to understand how this problem came about. It is equally important to understand the processes and practices used to address food insecurity and the potential impact of privatization. In terms of gathering information on SJSU's history of food insecurity, I collected observational data through my experience working within my role as the Program Assistant for the Food Shelf Program and member of the Student Hunger Committee over the course of two years. The Student Hunger Committee met once a month. The meetings were open to all students and members of SJSU. At these meetings, I took notes and all members were aware that I was writing my thesis on the topic of food insecurity. Additionally, I utilized documents shared with me to support my research. The following is a history of food insecurity at SJSU.

In the summer of 2010, the "Student Hunger Task Force" (now known as the "Student Hunger Committee") was commissioned by the VP of Student Affairs (History of SJSU Student Hunger Committee 2016). However, after the Fall 2014 "Student Food Access Survey" results indicated that at least a third of SJSU's student body was experiencing food insecurity, there was no campus-wide coordinated response by the University, despite the survey being sent out by the Division of Student Affairs. Instead, various departments reached out to the Student Hunger Committee, offering a table or bookshelf in their departments where food could be placed and be available to students. In 2014, there was slightly more campus awareness and more SJSU faculty and staff 
became interested in becoming involved with the Student Hunger Committee and its efforts.

In August 2015, a graduate student was hired to work part-time as the Program Assistant for the Food Shelf program out of the Cesar Chavez Community Action Center (CCCAC). The Department Manager of the CCCAC at the time was an active member of the Student Hunger Committee (History of SJSU Student Hunger Committee 2016). During the fall 2015 semester, the Program Assistant was primarily responsible for restocking the food shelves, organizing food drives, collecting surveys ${ }^{10}$, spreading awareness, and following up with any department interested in starting their own food shelf. During this time period, the Student Hunger Committee existed as its own group, not under the authority of any department or office within the University. At this point, no financial support was offered by the university. All members were continuing with these efforts on a volunteer basis. The University was reluctant to spend money to tackle this very large and prevalent issue affecting its student body, demonstrating the austerity practices found in organizations affected by privatization.

In October 2014, the Student Hunger Committee developed the "SJSU Food for Students Fund" (History of SJSU Student Hunger Committee 2016). As of April 2017,

\footnotetext{
${ }^{10}$ A survey was developed in fall 2015 in an attempt to keep track of the number of students who utilized the free non-perishable food resources offered on the food shelves. Between October 2015 and May 2017, 2,531 surveys were collected. This data is limited to the extent that it does not distinguish between students who have utilized a food shelf before. Furthermore, there are likely to be more students who picked up items from the food shelves but did not fill out a survey. Additionally, there may be times in which not enough printed surveys were available. Also, since there are 15 locations across campus and no one monitoring the areas at all times during the day, there is no way of forcing or even simply encouraging students to complete a survey.
} 
the fund currently has $\$ 35,588.71$, which takes into consideration the money used for monthly food purchases, marketing materials, fruit pickers, monetary collection bins, etc. (Student Hunger Committee Notes, 4/11/2017). Since the "SJSU Food for Students Fund" (now known as the "Student Hunger Fund") began, it has raised close to $\$ 60,000$. The lack of response by the University once presented with the problem puts to question whether low-income students who are food insecure are viewed as deserving of University support. It is likely that the delay in action by the University was because it would mean an additional expense on a grand scale.

The Food Shelf Program is one of the primary resources organized and developed by the Student Hunger Committee. The Food Shelf Program quickly grew from 9 to 15 food shelves within two semesters. The SHC currently spends $\$ 3,000$ a month to purchase food on a bi-weekly basis. The money comes from the "Student Hunger Fund" which is funded by online and cash donations collected by Spartan Shops in all the of the oncampus eateries. Spartan Shops is an auxiliary organization to the university that provides dining services to SJSU students. Since the inception of the "Student Hunger Fund," approximately $\$ 60,000$ has been raised. Additionally, the Associated Students (A.S) Board of Directors voted to allocate $\$ 500$ a month for the exclusive purchase of food (History of SJSU Student Hunger Committee 2016). The A.S. Board of Directors are student government representatives elected by students and are responsible for the operations of Associated Students and serving as an advocate for the entire SJSU student community. As of April 2016, a total of \$3,500 a month is being spent on food and coming directly from donations and students themselves. This decision to contribute 
financially to the Food Shelf Program comes after the A.S. Board of Directors passed the resolution: "In Support of a Comprehensive Plan to address Food Insecurity among SJSU Students" on Wednesday, April 27th, 2016. This resolution asks for a commitment by the University to continue efforts that will address food insecurity among students and that this be a campus-wide initiative (Associated Students, SJSU, Board of Directors' Resolution 15/16-05, 2016).

One of the resolutions listed is "That SJSU works towards establishing a centralized food pantry that provides both food and support to help students access existing campus, county, and community resources to address food insecurity and other issues they may be facing (e.g. homelessness, other financial concerns)" (Associated Students, SJSU, Board of Directors' Resolution 15/16-05, 2016). This is a example of representatives of the SJSU student body calling upon the University to meet its students' needs.

There are several key moments in the history of food insecurity at SJSU (both before and after the University's acknowledgement of the problem) that either served to extend or restrict resources benefiting students. During the spring 2016 semester, Spartan Shops hired one of the current Co-Chairs of the Student Hunger Committee. This committee member gained permission from Spartan Shops to be paid to work on issues regarding food insecurity on campus. This was important in terms of spreading awareness of food insecurity among students as well as gaining more resources to support students. This person has presented to approximately 60 classrooms, reaching approximately 1,800 students. At the inception of the Student Hunger Committee, there were two programs: The Food Shelf Program and The Breakfast Club. Currently, the 
food resources organized and run by the Student Hunger Committee are Cooking Healthy, Eating Well (C.H.E.W), Food for Thought, and Freshest Cargo. These resources also offer a variety of healthy foods to students for free or at a reduced cost on campus more consistently than what is provided by the Food Shelf Program.

At the beginning of the spring 2016 semester, Second Harvest Food Bank offered members of the SHC committee the opportunity to become partners. Second Harvest Food Bank is a non-profit organization that serves food in the Santa Clara and San Mateo Counties. It is one of the largest food banks in the nation. Between the months of June 2015 and July 2016, they distributed over one million pounds of food a week to lowincome and underserved people (Second Harvest Food Bank 2017). They have partnerships with 320 non-profit organizations serving 850 food distribution sites (Second Harvest Food Bank 2017). To accomplish this, Second Harvest needed 310,000 volunteers hours (Second Harvest Food Bank 2017). Furthermore, Second Harvest Food Bank of Santa Clara and San Mateo Counties offered to fully equip a fully functioning food pantry on the SJSU campus by providing a refrigerator, freezer, shelving, and ongoing supply of food at no cost to the campus. The University was also offered the opportunity to take part in the "Just In Time Mobile Food Pantry Distribution," which meant that Second Harvest would deliver perishable and nonperishable food items to the campus once a month for an hour and a half. In fall 2016, SJSU began a partnership with Second Harvest and the Just in Time Mobile Food Pantry program.

At the beginning of the spring 2016 semester, the University decided to officially launch SJSU Cares, an initiative led by Economic Crisis Response Team (ECRT) and the 
Division of Student Affairs (History of SJSU Student Hunger Committee 2016). SJSU is the second school within the CSU system to have an ECRT, the first being San Diego State University, where the former VP of Student Affairs worked prior to coming to SJSU. The ECRT was responsible for overseeing the operations of the Just In Time Mobile Food Pantry distributions. Since the first distribution in October 2016, there have been eight distributions reaching 2,245 unique students (Student Hunger Committee Notes, $5 / 11 / 2017)$

In April 2016, I was informed by a member of the Student Hunger Committee that a high-level administrator told them, their supervisors, and other staff to stop the idea of a centralized food pantry from happening. There was one point in which Student Hunger Committee members were told not to discuss the offer made by the Santa Clara County Second Harvest Food Bank. The actions and inaction taken by the University have an impact on the ways and extent that SJSU students experience food insecurity. These actions by the University seem to de-emphasize the needs of low-income and firstgeneration students who would likely benefit from having a food pantry on campus. Having a food pantry on campus would further establish the responsibility and precedent to address student needs and further ensure them with an environment to thrive academically. In doing so, this would likely incur a cost to the University as there would be demands for other student needs to be met. Despite efforts made by the SHC to locate a space with Buildings and Grounds, SJSU, to this day, does not have a food pantry on 
campus. Food insecurity is being addressed in numerous ways but none that would be as effective and holistic as a food pantry.

In May 2016, the Student Hunger Committee voted to become a part of the ECRT (History of SJSU Student Hunger Committee 2016). The purpose of the ECRT is to meet the needs of students experiencing a variety of economic crises providing food, housing, medical, and emergency assistance. For instance, upon learning that SJSU students' apartments had burned down, the ECRT called these students in the middle of the night and provided them with a place to stay, gold point cards (cards that could be used exclusively at on-campus eateries), and laptops. This parallels the action the ECRT took during the San Jose Flood in March 2017. Additionally, the ECRT has the ability to review a student's financial aid package and offer students loans, as well as adjust the amount of loans a student can take out. It is important to consider that this program offers students the ability to take out additional loans. Some may argue that loans may be seen as an investment. Yet, with trillions of dollars in debt, students may be increasing their risk of defaulting, which in turn is an investment for the companies and government entities managing the loans. Approximately, 200 students have been assisted through the ECRT as of May 2017.

In June 2016, the CSU System organized a conference entitled "CSU Conference to Best Meet the Needs of Housing Displaced and Food Insecure Students." This conference had participants from the majority of schools within the CSU system. There were several workshops, presentations, keynote speakers, and a student panel discussing the best 
practices that could be enacted by colleges and universities to address student homelessness and food insecurity.

Following this conference, members of both the ECRT and SHC met together and developed a list of recommendations for SJSU. These recommendations were then presented to the Board of Trustees by the VP of Student Affairs and a couple of other administrators. The recommendations were divided up among short- (6 months), mid- (12 months), and long- (three years) term goals. The majority of the short-term goals have been fulfilled. However, we are three months shy of when the mid-term goals should be met and the majority of them have not been fulfilled. One of the mid-term goals is to identify a space for a centralized food pantry. In several meetings and conversations with administrators, I've been told that there is just no space available for a food pantry.

The ECRT did decide to partner with Second Harvest Food Bank of Santa Clara County to bring the Just in Time Mobile Food Pantry to campus. This service occurs once a month on Monday from 10-11:15 a.m., when approximately 15,000 lbs. of food is delivered into the Event Center at SJSU (Student Affairs Newsletter December 2016). Students enrolled in classes at SJSU have their student ID scanned and sign a form saying they make under the poverty line for Santa Clara County, which is around $\$ 23,760$. Students can get both non-perishable and perishable food items (Student Affairs Newsletter December 2016). On average, 522 students each month have taken advantage of this opportunity.

At the end of the spring 2016 semester, the sole on-campus social worker left the university and someone within the department filled that role. Yet, with a population of 
over 32,000 students, one or even two Social Workers do not have the capacity to meet the needs of all students. This is something that should be asked of other campuses as well. There was discussion about hiring an additional Social Worker within a year, but that has not happened. For now, the ECRT has hired a case manager. This case manager works within the ECRT while also having the responsibility of coordinating ECRT efforts.

ECRT organized CalFresh ${ }^{11}$ Sign-ups to assist students in gaining money to pay for groceries. CalFresh allows those who make under a certain amount of money and meet other eligibility requirements such as U.S. citizenship to receive benefits from the government that can be used to purchase food. In Santa Clara County, if you are a parttime student and not working, you can receive these benefits as well. SJSU students may go to the Financial Aid Office and Student Wellness Center during a specific hour-and-ahalf time slot on Tuesdays and Wednesdays.

In the "SJSU's Four Pillars of Student Success: College Readiness, Advising, Student Engagement and Clearing Bottlenecks" report launched by the VP of Academic Affairs and VP of Student Affairs, various ways of improving the graduation rate within six years are discussed. In 2015, the graduation rate for after six years was $56.8 \%$, which is slightly lower than the national average of 58\% (Blaylock and Feinstein, 2016). In this report, there was no discussion of students facing food insecurity nor homelessness as a severe impediment to academic success, despite the CSU findings in January 2016. In

\footnotetext{
${ }^{11}$ CalFresh formerly known as EBT and Food Stamps.
} 
October 2015, Academic Affairs helped raise \$7,000 to contribute to the "Student Hunger Fund" (History of SJSU Student Hunger Committee 2016). The "Student Hunger Fund" was organized by members of the Student Hunger Committee prior to the merger with the ECRT. To date, the University Division of Student Affairs has not allocated funds to be used for purchasing food for the Food Shelf Program, despite the fact that this initiative potentially serves a third of the student population. This is a key example of public institutions taking part in austerity practices in which resources and funds that could be used to address student needs are not allocated for such purposes. This leaves food insecure students with a lack of resources that would help them succeed academically. 


\section{METHODOLOGY}

Individual interviews and focus groups were conducted to assess how students attending SJSU experiencing food insecurity defined food insecurity as well as whether it impacted their physical or mental health. There is not much qualitative research on college students experiencing food insecurity, an issue this research intended to address. Interviews provide the unique ability to ask open-ended questions, facilitate broader discussions, and gain more meaningful responses.

A total of 16 students participated in this research. All participants were current students attending SJSU. The majority of participants were female (14), while 2 were male. Participants' ages ranged from 18-23. All students were students of color: six identified as Latinx, eight as Asian, and two as African American. The race and gender of participants can be seen in Table 1. The majority of participants (14) were food insecure while two students never had an experience with food insecurity. The majority of participants indicated that they were from a low socioeconomic background. Additionally, 15 out of 16 participants were full-time students. The majority of these students (11) worked on-campus, while three worked off-campus and two worked both on and off campus. Their yearly income varied from $\$ 800$ at the lowest to $\$ 15,000$ at the highest. Based on these numbers, all of the students were living near or in poverty. There were six students who did not know their yearly income and did not approximate. The majority of participants (11) lived off-campus and rented in San Jose, while five students paid for on-campus housing. There was one participant who lived with her family at home but still contributed financially to their rent. Participants food security status, living 
arrangement, student status, and working situation can all be seen in Table 2. All but two participants were either juniors or seniors. 
Table 1. Participants by Race and Gender

\begin{tabular}{|l|l|}
\hline Gender & Participants \\
\hline Female & 14 \\
\hline Male & 2 \\
\hline Race/Ethnicity & \\
\hline Asian & 8 \\
\hline Latinx & 6 \\
\hline Black & 2 \\
\hline
\end{tabular}

Table 2. Participants Food Security Status, Living Arrangement, Student Status, and Working Situation.

\begin{tabular}{|l|l|l|l|l|l|}
\hline & $\begin{array}{l}\text { Food } \\
\text { Insecurity }\end{array}$ & Renting & $\begin{array}{l}\text { Living Off- } \\
\text { Campus }\end{array}$ & $\begin{array}{l}\text { Full-time } \\
\text { Student }\end{array}$ & $\begin{array}{l}\text { Working On- } \\
\text { Campus }\end{array}$ \\
\hline Yes & 14 & 11 & 11 & 15 & 13 \\
\hline No & 2 & 5 & 5 & 1 & 3 \\
\hline Total & $\mathrm{N}=16$ & & & & \\
\hline Participants & & & & & \\
\hline $\begin{array}{l}\text { Total } \\
\text { Interviews }\end{array}$ & $\mathrm{N}=19$ & & & & \\
\hline
\end{tabular}

Flyers (see Appendix B) announcing the purpose of the research, compensation, and times and dates of the focus groups were hung up at all 15 of the food shelf locations (see 
Appendix C). Flyers were also placed in the following departments of the Student Union as well as the two information desks located at opposite entrances of the Student Union. The Student Union is a central location on campus and was recently renovated. It holds the majority of the on-campus eateries, ballrooms, meeting rooms, and many seating areas and tables. An electronic version of this flyer was also sent out to the heads of the Latinx/Chicanx and African American Task Forces. The representative from the Latinx/Chicanx Taskforce sent the flyer out and the representative from the African American Task Force said that they did not send mass emails of flyers out regularly. A flyer was also sent out electronically to members in the Asian American Pacific Islanders Coalition. On the flyer, those interested in participating were encouraged to either email me or text/call my cell phone. All but one participant decided to email me, and they texted my cell phone instead.

I conducted three focus groups, which had a total of 12 students. The interviews were held in a small study room that had to be reserved. Participants were informed at the end of the interview that if they would like, they could participate in an individual interview at a later date and time of their choosing. Two participants from the focus groups participated in individual interviews, and there were six interviews in total. These interviews were all conducted in library study rooms. All interviews were recorded and transcribed. To recruit students for individual interviews, students from the focus group were asked if they would like to participate, which one student agreed to. Two other students graduated, and another student moved out of state and left SJSU. Similar to the recruitment procedures for participants in the focus group, flyers were placed at the 15 
food shelves across campus, in several departments in the Student Union, as well as at the information desks. There were a total of eight students who participated in the individual interviews. Unfortunately, three of the transcribed files were inadvertently deleted and another two students were interviewed, making a total of six individual interviews. Questions in the individual interviews were centered on what these students' experiences with food insecurity were like, their coping strategies, what resources they were aware of and/or utilized, who knew about their food insecurity, and what they would recommend for SJSU to do to address food insecurity.

Interviews were first transcribed, then a memo was written for each one. Each interview was coded for general patterns and themes, then for specific themes, and then for a third time using the specific themes that were developed based off of information gathered from the interviews. Information regarding SJSU's response to food insecurity was gained by attending public Student Hunger Committee Meetings. The Student Hunger Committee first began as an informal group of staff, faculty, and students who met once a month to spread awareness and gain resources to address food insecurity at SJSU. Eventually, the Student Hunger Committee became part of SJSU's Economic Crisis and Response Team run out of the Division of Student Affairs. Focus group interviews lasted on average for 30 minutes. The individual interviews lasted an average of 20 minutes. Memos were written up after hearing each of the interviews and were used to identify a number of themes across interviews. More focused coding revealed 4 specific, consistent themes: Defining Food Insecurity, Health and Mental Well-being, Poverty, and Coping Strategies. Defining Food Insecurity refers to the students' 
familiarity and usage of the term as well as how they would define it. The Health and Mental Well-being code discusses students' physiological, psychological, and emotional responses to being food insecure. Poverty discusses students' experiences growing up poor and, in some cases, food insecure as well. Finally, Coping Strategies refers to the methods in which students deal with their food insecurity, whether that be in the form of distraction, limiting food intake, or finding food resources. Additionally, students' ideas and suggestions about programs dealing with food insecurity were also identified and will be discussed further in the Discussion section along with other best practice suggestions.

\section{Intersectionality}

Intersectional approach examines multiple identities, structures, and processes and how they relate to and impact one another. By using an intersectional framework, we are able to learn more about the way that power operates on a day-to-day level and how interconnected systems (such as capitalism, racism, and patriarchy) shape and are shaped by equally complicated individual experience/agency. Intersectionality is an appropriate framework for studying college students experiencing food insecurity because they have multiple identities and experiences impacting the ways they cope with food insecurity and their perception of themselves. Further, as discussed at length above, their food insecurity is largely an expression of structured inequality, caused and shaped by overlapping systems of oppression. Intersectionality has the ability to examine all of these identities at once and their relation to one another. By adopting an intersectional framework, we can better understand the various factors contributing to a student experiencing food insecurity. The contributing factors to students of color experiencing 
food insecurity are complex. It is important to examine the various historical, racial, gendered, and institutional experiences simultaneously, as it reveals insights that are not completely understood when they are studied individually. Furthermore, an intersectional approach will enable us to better analyze the convergence of food insecurity, poverty, college life, and systems influencing higher education.

\section{Institutions of Power}

While examining college students' experiences, it is equally important to look at the institutional structure of the college these participants attend (Gouldner 1968). Becker (1963) emphasizes that in sociological research, there is a tendency to study people who are oppressed. He posits that by doing so, information is collected on those who are oppressed to then be utilized by the very institutions that are responsible for their marginalization. He poses the question to sociologists, "Whose side are you on?" in an attempt to get sociologists more critical and aware of the impact that their research has on the people they study. Becker alludes to sociologists taking the task of studying those people and institutions in power, which has an impact on the people being studied and/or oppressed (the underdogs). Additionally, what is known regarding those at the top, and what influence do they have upon underdogs? Therefore, examining how SJSU defines and addresses food insecurity will provide more insight into the historical and systematic practices taking place within the institution. 


\section{RESULTS}

The purpose of this research was to better understand how SJSU students experience and define food insecurity. The key questions investigated include: (1) How do SJSU students experience and define food insecurity? (2) How does SJSU define and address food insecurity and to what extent is the private sector involved in SJSU's approach towards addressing food insecurity? Through a series of focus groups and individual interviews, there were some major findings that emerged and were grouped in the following categories: defining food insecurity, health and mental well-being, poverty, and coping strategies. All students agreed that food insecurity was a result of not being able to afford food. Some students also mentioned the lack of choice they had to pick the food they wanted, and a few lamented that they were unable to afford the healthier options. Not knowing when and where their next meal was going to be caused many students stress and negatively affected their mental well-being. Students also expressed feeling embarrassed about being food insecure. Many of the students grew up in households with low socioeconomic status, and that was an important big factor in terms of not telling their parents they were struggling with food insecurity. To get by, students sought food resources, received assistance from friends and cut their meal size by saving food or skipping meals altogether. Summary and direct quotes from the students' interviews can be found below as well as an analysis, which draws upon literature from the fields of poverty, food insecurity, higher education, and privatization of higher education. 


\section{What is Food Insecurity?}

One major finding is that although the world of academia is now familiar with the term "food insecurity," the majority of students in this study were not. However, upon hearing a definition, the students immediately related and could identify with the experience. The majority of student participants defined food insecurity as not knowing when their next meal is going to be due to a lack of financial resources. Several students also indicated a deterioration in health due to not being able to afford nutritious food. One student, Beatriz, states her experience keeping track of her diet: "All semester we had to do a project in my Nutrition class like you had to log stuff you ate, and I like started to realize how vitamin deficient I am just from all of the foods I don't really eat and just like how little I eat." She continues by saying until then she didn't really realize she was food insecure. Moving forward, to best get students to self-identify with food insecurity, the following questions should be asked: do they skip meals, cannot afford to eat out, have an empty fridge, or feel they have a tight budget? Students may have an easier time relating to the experiences rather than the term food insecurity.

Many students were unfamiliar with the term "food insecurity" and found themselves relating to the definition once other students explained what they thought it meant. Students also stated that they would not personally identify themselves with the term due to fear of stigmatization. For example, Marisol states: "I would say no because sometimes other people don't understand what you are going through so you could just be like, 'Oh, I'll just eat at home' and you know just so that they don't ask you anymore 
questions." Many students understand and have lived through the experiences of being food insecure but have never heard of or used the term food insecurity.

Beatriz reflects upon first learning of the term food insecurity in one of her Nutrition classes: "I remember when we first learned about that topic, a lot of people in class were just nodding in agreement. Like, 'Wow that's us college students, we do face this.' So I don't feel that alone. I just feel that most people just don't know the term for it." Nicole responds: "Yes, I haven't used the term specifically, but I have experienced that this semester and previous semesters." Furthermore, she explains that due to employment difficulties, she was unable to make the money needed to purchase food and would therefore resort to utilizing the food shelves or other friends would help buy her food.

Similarly, Valeria mentions that "If I'm able to put in more time at work then there is time that I can go bring food home versus if I'm more busy like during midterms and finals, which means I can't work more and can't go buy more food.” Valeria's comment indicates that many students are working for their livelihood and survival. Valeria does live at home with her parents; however, she contributes financially by helping pay rent, bills, and other expenses. Furthermore, she prioritizes being a student and studying for her major exams as well, which is something that many college students who are food insecure must deal with. Not working is not an option for Valeria and many other students coming from a low-income background. Food insecurity is also about a lack of choice due to being constrained financially. One student states: "[N]ot being able to choose what you want or spending your resources and money on things you can afford as opposed to things that are good for you." This student reflects that what she can afford is 
not the healthiest. Rochelle agrees when she points out that what she considers food insecurity is "I guess not eating enough and not having proper diet and nutrition that each person needs to have each day." This statement points out that food insecurity is detrimental to one's health as well. Furthermore, in order to succeed academically to the best of one's ability, being able to eat consistent and nutritious meals is extremely important. SJSU needs to prioritize student needs by providing them with the resources that will help ensure their academic success.

\section{Lack of Health and Mental Well-Being}

One of the most common themes in my focus groups and interviews was the stress students felt as a result of not being able to eat and not knowing when they would get their next meal. Justine said that one of the challenges of being food insecure is " $[\mathrm{N}]$ ot being able to focus just because of not being able to eat. Oh, when am I going to eat?" Arlene agrees with the statement and adds: "And being tired and not focusing or not having motivation to do your work, which affects academics and all that." Many students also mentioned that they felt tired due to not eating full meals consistently. Marisol adds:

You feel extra tired. You go to sleep and you get 6 hours or so and you wake up and you're like I'm still tired. And sometimes not even water. . you're just drinking water and sometimes it doesn't do it. I feel like you're extra tired and you're not fully on your best in class to actually understand and learn what you're taught. So, I think that that's one of the things that impacts me the most.

Marisol expresses a poignant concern that her inability to eat on a consistent basis is affecting her ability to learn most effectively. This is crucially important, as all students 
attend college to learn and obtain a degree, but unfortunately, experiencing food insecurity can make this difficult. Sarah also mentions trying to cope with her food insecurity and eagerness to study by drinking water. She recalls: "Sometimes when I'm hungry like in the middle of the night I just it's uh. ... I don't have the energy to study and I feel really sleepy and tired so I just drink a lot of cold water to freshen me up and that's about the most I could do." Sarah is trying to stay up and study, but she does not have enough energy. She knows and wants to study, but her body will not let her. Food insecure students struggle to be responsible and prioritize their classes but often are unable to do so because their health is in constant jeopardy. This is true for a third of the population at SJSU.

When I asked students how life would be different if they were not food insecure, Maddy responds: "Maybe mentally awake and more active. You know how we were talking about not having lots of energy then you can't join other clubs and activities that everyone else is doing. So it can definitely get you more involved, feel more concerned." Despite this statement, many students were involved in a variety of activities outside of school and work. Valeria mentions that she was good at soccer and interested in the intramural team, but it was too much of a time commitment. Time that she needed to work in order to pay for her necessities and help out her family. Arlene did mention that if she was not experiencing food insecurity that "I'd go out, spend time hanging out with friends, and increase my social interactions and all that too." Students felt that if they were not food insecure they would have more energy to be involved in college activities. 
Several students noted that there were times when they had to make excuses to not hang out with friends because they could not afford to eat out. Justine comments: "I mean there definitely times when your friends are going out but you can't. You just feel alone." Furthermore, Rochelle says that it is sad being hungry but not being able to have food is something that would be embarrassing to admit to friends as a reason for not being able to hang out with them. This may be why Maddy stated:

I also want to point out that I think it isolates people. Maybe friends are going out to eat and then like Oh, I can't. So it takes away social aspects. And also, I think that even eating with other people is another big social part in life and .. . uh it's uh. . . you might keep it to yourself because you don't want people to ask you either. So you might not even hang out with friends, you might just sit in your room. That kind of isolation.

Some students, to avoid feelings of embarrassment and shame, would isolate themselves, which is the opposite of what colleges encourage students to do. Additionally, this social isolation may cause feelings of sadness and stress due to not being able to eat nor engage in the social activities that students would like to. Only one student mentioned not being able to eat, which resulted to being sick. However, all participants stated it was something that was tremendously stressful to deal with on top of being a college student. College students coming from low-income backgrounds do not have anyone to rely on for financial support. Students are working for their own survival and must balance trying to sustain themselves with their academic priorities.

My informants felt that food insecurity also negatively impacted their mental health. Maddy told me: “[I]n terms of Maslow's Hierarchy of Needs, if you don't have food it's 
hard to reach the top." Valeria would often feel sad because she knows what she is supposed to eat to be healthy, but she just can't afford it and lacks time to prepare meals. She exclaims: "Well, it sucks because you see all around you, 'Oh you should have this much vegetables, this much fruit like you should be eating this.' But it's so. . . because first of all, you have to prepare that kind of food to eat healthy versus eating fast food. It's just cheaper and faster." Valeria struggles with both affording food and finding time to prepare food, as she is a part-time student and works full time. She works not only for her own survival but to assist her family as well. Additionally, she is being charged international student tuition. College students are a unique population experiencing food insecurity because they must balance work, family, social, and academic priorities when considering how to cope with their food insecurity, which is something the general population does not have to do.

A few students did state changes in their body due to being food insecure. Nicole admits that: "I actually did lose some weight cuz of my budget. I didn't have any money to eat." Xiomara also lost weight but viewed this positively because it encouraged her to search for affordable food that is also healthy. A major setback to food insecurity for her was constantly being stressed about buying groceries and living paycheck to paycheck. Aadarsh says that he eats one meal a day and other small snacks throughout the day. He feels that “[S]ometimes I don't think people take me seriously because I'm not well-built, which he attributes to not being able to eat as much food. Being food insecure can also impact one's perception of their body as well. 
Isabella believes that having CalFresh (EBT) has helped her combat food insecurity because she can go shopping without having to worry about money. CalFresh provides a monthly stipend that can be used to purchase groceries and fruits and vegetables at the Farmer's Market. However, CalFresh is not available to international or undocumented students. It is critical that low-income students have access to these resources, as their family is often times struggling and cannot provide them with financial support. Yet, these are the very resources that are in danger of having their funding cut and given to private companies or individuals, as can be seen with the passage of the most recent tax bill (NY Times, Sorkin 12/18/2017). More and more, we are seeing the ways in which public governmental funds and resources are redirected toward private corporations that will maximize profit for their shareholders.

Petra tries to cook healthy and would obtain many fruits and vegetables for free at the community garden located on-campus. Beatriz also goes to a community garden within the city of San Jose. However, a study conducted by Freudenberg et al. (2011) revealed that $63 \%$ of students receiving food stamps were still food insecure. Another study conducted by the Wisconsin HOPE Lab, which included 4,000 community college students across that nation revealed that $11 \%$ of the students participating in their research were still food insecure (Goldrick-Rab 2015). People living in poverty do not get enough government assistance. The definition of poverty, developed by Mollie Orshansky in 1967, is making under three times the amount needed to purchase groceries. Additionally, people working and receiving minimum wage are still struggling financially. Living in poverty does not generate the property taxes for a quality education. 
The lack of a quality education leads to poor paying jobs and the cycle repeats itself generation after generation.

When asked how students would define food insecurity, Nicole mentions that as a student, you are afraid to ask for help from other people. Rochelle mentions the struggle of having to decline invites from friends to go to lunch and keeps her food insecurity hidden because she would be ashamed and embarrassed if others found out. Throughout the focus group and individual interviews, other students have made comments that echo the previous statements. Previously mentioned, Marisol avoided the discussion altogether because of the fact that some students do not understand her experience. Xiomara recalls an incident with one of her friends that did not have a comprehensive understanding of food insecurity. When asked about how experiencing food insecurity made her feel, she states: "Kind of sad sometimes cuz, when I talk to like a close friend of mine and he means it jokingly but like "All you're eating is rice and beans.” And I'm like yeah because it's all I can eat like." Beatriz also mentioned, the difficulty of having to watch her roommates eat while all she eats for the rest of the week are cans of soup. Nicole remembers having no budget for food at all and solely relying on the food shelves around campus. Eating one type of food due to financial restrictions is a very stark reality for students experiencing food insecurity, but there are some students who do not understand this and decide to poke fun instead. The comment made by Xiomara's friend made her feel sad and ashamed that she was unable to provide more for herself.

When asked about whether they knew of other students who experienced food insecurity, some replied that they did, and they usually were close friends or are 
roommates living together who could observe each other's eating patterns. Several students did not know other students facing food insecurity. Sarah mentioned how she did not know any other students who share her experiences and that she doesn't go around asking students about it, and it is not information other students are likely to offer up.

\section{Growing up in Poverty}

Many of the participants discussed that they grew up in poverty and that their family is still struggling. Many students coming from low socioeconomic backgrounds and working to support themselves did not seek out assistance from their parents and did not let them know they were facing food insecurity. These students did not want to be a financial burden for their family, who they knew were struggling. In some cases, these financial constraints translated into food insecurity as well. When asked whether students had prior experiences with food insecurity, Xiomara states:

"Yeah, well I come from a low-income family of six and there's just ... I've always just grown up with the attitude of "Oh, I can get this at the Dollar Store" or "Oh, that's too expensive, I know somewhere else I can get it cheaper. So, I came ... I think it's been ingrained in me, so I kind of know how to shop for that already."

In response, Nicole said: “I agree. I mean my Mom’s a single mom growing up with that attitude because she was the only income, so I learned how to bargain and stuff as well." Both students had experiences seeing their parents negotiate and determine the best prices for food. As previously stated, there would be times when Xiomara would eat only rice and beans. She also freezes food to try and make it last longer. In spite of 
having these skill sets, both students still found themselves struggling with food insecurity in college.

Beatriz also remembers the financial difficulties that her single mother had in raising her and her four siblings but, she also remembered that her mom always made sure that they ate every day. Sarah also recalls her parents struggling financially as well:

"I don't think it was as bad as a child just because I have my parents. Yeah, as a kid I don't think I struggled as much because my parents were there for me. I mean I do remember times when I figured we weren't that well off and could afford whatever we wanted because my parents would always get things to go if they don't finish at a restaurant. Or like if I was having a class party or something they would tell me to grab some leftovers to bring home."

Sarah recognized that although her family did not struggle tremendously, they were not well-off and did need assistance from time to time. Isabella also recalls her mother always providing food for her: "But we always had food in the table so it didn't make me feel that bad. I did feel frustrated for her because I always saw her struggling kind of." Single mothers are disproportionately represented in poverty and have consistently struggled with receiving the requisite amount of funds needed to help raise their families (National Women's Law Center, 2016).

Petra remembers being frustrated at seeing other students eat at lunch time because her parents would give her a few dollars to eat, but then that would run out, and since her family was middle class, she did not qualify for the free lunch program in high school. Valeria remembers experiencing food insecurity in high school: “. . .I was on the soccer team and I remember being super hungry after and my mom would have the food because I didn't work, and I remember not eating as much as I wanted to because I know my 
parents and my brother and sister have to eat. Growing up, there may not be enough food, but there is enough for everyone to still have something." Sharing food is a value that she mentioned previously in discussing how her family would try to teach her little sister the importance of sharing and offering food. Growing up, she would also ask her classmates for their extra milk and carrots that they didn't eat. For Marisol, poverty, including food insecurity, was a stark reality. She recalls:

Yeah, I grew up in a third-world country so um yeah we didn't have a lot of money so whatever my mom and my dad sent us from here to where I'm from would be everything like our budget really for the whole month. I used to live by the beach and we'd ask for fish or something or go out and see what fruits were on the tree it was always like what you're eating is tortillas, cheese, cream, that's about it. Oh and rice and beans so it wasn't like you had a lot of choices. It was either that or you go ask for food for us personally.

In the United States, her family still struggled because it was just her mom raising five siblings and working a minimum wage job:

Basically, a lot of the money went to rent and bills and stuff like that. Food was a little more of like sorry we don't have enough money for that. So we'd go to a church and get food from like a food bank or something. So, that would be our resource for food. But my whole career from San Jose was starting from that and then here and now yeah.

For Marisol, poverty is something that her and her family are still struggling with, and it is not hard to understand why she is now food insecure while attending college. She relied on food banks and churches for food; a few other students mentioned using these resources as well. 
In Valeria's case, she works to support herself and her family: "It depends on my parents. They are the ones who take care of bills but I help. Depending on what they tell me. Like 'Oh we need this much money for this or that.' Whether it's car insurance or paying the bills. The lowest I've had is $\$ 200$ but it's gone up to $\$ 1000$." She is a student who works, pays her tuition, and helps her family subsist. Beatriz discusses the struggle of students being on their own for the first time and not being able to rely on parents for financial resources: "I mean there's a lot of students who are out here on their own for the first time and they really have to be able to balance the money they spend on food. And not everyone's parents give them money to go grocery shopping, like mine don't, and it's kind of hard with my friends who have parents who give them everything." Many students who are first generation and come from low-income backgrounds must provide their own financial support as their families are struggling.

There are many first-generation students who come from a low socioeconomic background. First-generation students are more likely to live in poverty (Inside Higher $E d$, Ashley A. Smith, 9/27/2017). First-generation students are motivated to do well in college to improve the life opportunities for themselves and their family (Wheeler 2016). This may be the reason why many first-generation students are more likely to work and contribute financially to their family (Engle and Tinto 2008). When asked why she decided to go to college, Sarah responds: "I decided to come to college because neither of my parents went to college. And I feel that they wanted me to go to college so that I can kinda do better than them because they didn't even graduate high school. So they wanted 
me to create a better future for myself and they saw that education was a huge part of that." Sarah feels a responsibility to go to college and to do better than her parents.

Valeria also decided to come to college to help others. For Beatriz, she attends college "so that I can get my education. I'm the first one in my family so it was like expected of me. But, as a millennial, it's kind of expected of everyone. And the job field is just so much more competitive now so I feel like you do need a degree in order to get a job." Beatriz expresses how she faced familial pressures to attend college as well as economic ones. Isabella discusses a program she's a part of, the Educational Opportunity Program (EOP), which is designed specifically to help first-generation college students. She discusses what the program provides: "They offer workshops, tutoring, free tutoring, free advising, like mentors. I had a mentor my first semester. And um it's cool they offer a lot of stuff. Oh, they give you grants. Yeah, it's a really good program. It's for firstgeneration college students who are lower income as well." First-generation college students do not have the same familiarity with the college system that students whose parents attended college do. Therefore, there are specific resources and funding available to help these students out, since many do come from a low socioeconomic status, such that financial constraints inhibited their family's ability to attend college for several generations.

Several of the students who were food insecure discussed not wanting to tell their parents or ask their parents for money. When asked why this was the case, Petra responded: "Because I have a little sister and then my parents are like, I don't want to say they're well off because they're working class. They use every cent of their money for 
bills that they pay." Petra mentions that her parents are still taking care of her younger sister and that she feels like she would be taking away resources needed to raise her. Furthermore, she felt relief when she was no longer on a meal plan because that was an additional $\$ 2,000$ that her parents did not have to spend.

Trying to do right by one's parents and family is something that Valeria has struggled with as well: "I don't like telling my parents that I do; so I'd rather buy on campus. And I just don't want to worry them. (Sobbing) I'd say it can be hard." Additionally, she spoke of her concerns of appearing well-off but that in reality she is not, which makes it difficult to utilize the food shelves. Valeria feels pressure because she looks like someone who doesn't need help and is worried that she will be judged negatively if she gets food from the food shelf because people will think that she does not deserve it. She is also concerned that there are students who need the food more than her, so she tries to avoid utilizing them. The food shelves were never meant to be a permanent solution. They were a temporary resource for students facing immediate food insecurity. However, by not dedicating resources and funds from the community or the University that would benefit a large number of students, such as a central food pantry, students like Valeria will remain hesitant to utilize what is currently available because they know that there are so many other students out there suffering. Valeria, who is undocumented, struggles feeling like a burden to not only her family and professors but the entire nation: "I think with my parents because they are working so much (crying). I don't want to be like a burden (crying). And then at school, I feel like it's not the professor's job or anybody's job to do that. Like and then being undocumented they look at you like the people in charge or the 
people with the power like you're just there to take advantage of it even though you need it." Valeria feels immense guilt for needing food resources and feels shame because she believes that other people are not responsible for her not having food. Furthermore, by being undocumented, she faces stigma that labels undocumented people as taking advantage of the system.

Beatriz retells how her mom found out through an uncle that she was experiencing food insecurity and her mom was kind of upset and said that she could have given her money. But Beatriz said that she did not like to ask her mom for money because she knows that her family struggles and did not want to cause additional stress to her mother. These students do not rely on their family for money because they understand the financial struggles their families endure, and they don't want to place an additional burden on their loved ones. More and more students find themselves in this situation because of the increase in tuition and rent prices.

Rochelle says that people are afraid to get help because they do not want to feel ashamed, and therefore, there should be efforts dedicated to motivating people to utilize these resources and not feel ashamed. Their advice to other students experiencing food insecurity:

Rochelle: Don't be afraid to go to the food pantries. Like I know that when you are going there you don't want people to like see you go there. So one thing is don't be afraid — just do what you need to do.

Arlene: Know that there are so many students out there going through the same thing. That it's a common thing as opposed to an individual. 
Justine: Don't be ashamed. Take advantage of your resources and just know that this could just be a momentary lapse. It'll get better. You want to eat so that you can go throughout your day, go to school, go to work and that it'll all pay off eventually. So hopefully one day you won't have to go take advantage of food pantry resources; you can help those resources.

Marisol: I think you have to take advantage of them because they'll just go bad. Like who's going to eat it? Because everybody's like 'Nah. I don't really need to go.' Like no, you should go or else it'll go to waste unless you have it.

Maddy: Because if you are not healthy than you are going to be sick and not able to go to school and everything else kind of just drops. And I also think that for people who might not experience food insecurity and for everyone just be an advocate let everyone know what's going on. Yeah, spread the word.

These students view food resources as critical to their academic success, health, and mental well-being. Yet, the stigma students face often keeps them from seeking help. More attention and resources are needed to combat the stigma surrounding food insecurity. These students are encouraging other students to get the food resources they need and do what they need to do without feeling stigmatized. Furthermore, students hearing this message from other students are more likely to trust one another and not feel ashamed of speaking to or seeking help from other students because students view each other as equals. Therefore, in moving forward, students should be at the center of efforts designed to combat food insecurity among college students. There needs to be long-term planning and resources invested in these efforts, which ultimately will not yield a profit for the university because it is not a private enterprise. It will, however, fulfill the University's mission of addressing student needs and improving the quality of their education. 


\section{Coping Strategies}

Students shared several ways they coped with food insecurity. Valeria discusses how she will buy a large meal on campus and eat it throughout the day. She also tries to have leftovers for the next day and make food last as long as it can. Sarah only eats two meals a day but tries to time them so that she will not be hungry. Aadarsh eats one large meal a day and several smaller supplementary snacks. Valeria also attempted to distract herself by going to the gym because she feels that by exercising, she is not focusing on food. Sarah attempts to drink lots of water to fill her up. Aadarsh drinks a lot of milk to fill himself up. Jasmine picks fresh fruit from the trees in her neighborhood ${ }^{12}$. Beatriz has a meal plan that is good for 20 swipes during the semester. She says that she uses it when absolutely necessary and mostly to stock up on fruit. Sarah works on campus and has access to a meal pass. Meal passes give employees a 50\% discount on days that they work; Sarah works 5 days a week and takes advantage of this benefit. Beatriz utilizes a community garden in San Jose, and Petra has utilized the community garden on campus to get free fruits and vegetables. Isabella has utilized several food resources including CalFresh (EBT) ${ }^{13}$, the Food Shelves, the Breakfast Club, as well as attending free food events on campus.

\footnotetext{
${ }^{12}$ The USDA defines gleaning as "the act of collecting excess fresh foods from farms, gardens, farmers markets, or any other source in order to provide it to those in need-is an important source of fresh produce for food insecure families (USDA Office of the Chief Economist).

${ }^{13}$ CalFresh is the federally and state funded government program that provides money for groceries to people living in poverty within California. The national program that provide money for groceries is know as SNAP (Supplemental Nutrition Assistance Program). EBT stands for Electronic Benefits Transfer, which was formally known as Food Stamps.
} 
Sarah was excited about the Just in Time Mobile Food Pantry and made sure to go every month. However, she wishes that it occurred on different days and times because her schedule changed, and she was not able to skip class to go. The mobile food pantry is disadvantageous to many students and is a consequence of having a program that serves as a short-term fix and not a long-term solution. Several participants indicated that they utilized the on-campus food shelves. However, after the third focus group, students discussed the difficulty in locating the food shelves and did not know the exact number of food shelves on campus. Nicole mentioned having to run around all over campus just to locate the food items she would need and how that would take up hours of her time. Aadarsh also encountered difficulty obtaining food from the food shelves. He remembers going to a food shelf, not finding any food or anyone to talk to and deciding not to go back because there were no resources there. With a central food pantry, this problem would be averted.

The food shelves provided at SJSU were only intended to be a temporary fix. They have been able to provide support to thousands of students over the years, but is difficult for students to find out about and locate, and there is stigma surrounding its utilization. When it comes to the issue of food insecurity, SJSU has engaged in austerity practices, which has resulted in a delayed response to its approximately 11,000 students who are food insecure. Additionally, a minimal amount of financial resources has been contributed by the University. Furthermore, when given the opportunity to partner with Second Harvest Food Bank of Santa Clara County, the administration of the University advocated not having a central food bank on campus, despite the capacity of this resource 
to serve many more students and provide them with a healthier variety of both nonperishable and perishable food. By examining the trend of privatization in higher education institutions, we can see that resources intended to aid students and address their needs without a profit to be gained are kept to a minimum in favor of profit-earning enterprises.

Isabella discusses her struggles with food insecurity and how CalFresh was a huge help: "At first, before EBT, honestly it was really hard. And I would feel bad because like my boyfriend would always be paying for my food. I'd be like

No, don't. I can just make something little at my house.” But before it was hard honestly. Cuz, I would only have like $\$ 17$ in my bank account. So I couldn't really spend it in case of emergencies. And yeah, I would just make sandwiches or something or quesadillas. Little things you know. Now having EBT it's easier. I can just go shopping without worrying about my money.

By using EBT, Isabella has more freedom to purchase the food she needs. Additionally, she does not feel guilty for accepting help from her boyfriend. Maddy also enjoys using CalFresh because she does not have to worry so much about price but rather the quality of the food she is buying. Xiomara tried to apply for CalFresh but faced some difficulties: "Before this I looked into applying for the EBT and SNAP for our state but it's such a lengthy process you have to wait a month for it to process and there's certain things you can sign up for so you have to wait a month to get it so I didn't try it anymore because it was too difficult a process." SJSU does offer services to both check a student's eligibility and help them with the application. CalFresh is a great service for the community and students, yet there are still those left out. Marisol recommends that "maybe if CalFresh was okay with undocumented students because there's a lot of undocumented students 
on-campus and we don't get to have as much resources that other students do. So I think that if it applied toward undocumented students it would help me personally." It is important to try to make resources that are inclusive of all communities, especially those that are systematically oppressed. Furthermore, in Santa Clara County, there are more CalFresh resources available because less than half of those eligible sign up (Second Harvest Food Bank). More funding should go into designing a program that helps fight the stigma surrounding receiving free resources from the government.

Many of the students received help from other students who would offer to buy food, lend money, share food, and share resources. But they, as students experiencing food insecurity, felt bad because they were being a burden to their friends. When asked if anyone has been able to help or what ways have they helped themselves, most students discuss the various food resources available to them. Valeria however, was the only student to discuss working more. Deciding whether to work more hours is a difficult decision for many college students to make because many students discuss constantly being busy with studying, working, classes, and extracurricular meetings. Rochelle takes this point home by stating: "And also, I know that it's a lot cheaper if you cook your own meals but, I'm so busy with school sometimes I don't even have time to cook and save money." Finding time to cook and go grocery shopping can be difficult but the students interviewed discussed how their friends and roommates were able to help them. Aadarsh and his roommates would pool money together to buy groceries as well as cook meals together. This lasted for a while but unfortunately, due to having varying class schedules, they could not continue. Beatriz discussed going grocery shopping with friends who have 
a car, which helped save time and energy. Petra talked about the importance of selfreflection regarding whether or not she is spending her money wisely and budgeting. She also knows how to cook and feels that she spends a lot of time cooking and meal prepping but thinks that it is very rare to find college students who know how to do that. Xiomara has a budget while shopping: "I think just recently when I went to go buy groceries (little laugh) I would have a budget and wouldn't realize I would have to go and look for things on sale and just like learning how to make it last longer I have to freeze everything now (light laughter) so that it would last longer." Her testimony indicates that even while shopping on a budget purchasing food is still a struggle for those who are food insecure because they are financially limited. It is not necessarily the case that students are wasting their money, but rather, they do not have money to waste or even purchase basic necessities such as food. 


\section{BEST PRACTICES}

\section{Central Food Pantry}

A best practice for moving forward is to provide students with a centralized food pantry. Students can pick up the food they need throughout the day as well as talk with other students and staff about additional resources that may be beneficial to them. Furthermore, when students are searching for help, they may be in crisis and need food right at that moment. It is important to provide a space to have a conversation and provide reassurance to students that they should not feel ashamed about seeking help. Students may feel less stigmatized when interacting with other students who have experienced their same struggle. A single point of contact was recommended after a study was conducted on the California State University System by researchers from CSU Long Beach. Having one central location yields tremendous benefits in terms of marketing and spreading the word. Students, staff, and faculty can more easily inform students that there is a single location in which food and resources can be found.

Additionally, by having a single location, a refrigerator could be provided and monitored, which would allow students access to healthier perishable items such as fresh fruits and vegetables. Furthermore, if a single person were to work in the location they could spend time recruiting and coordinating volunteers and student assistants. More time could be spent having conversations with students and developing programs that could help combat stigma and raise more awareness of both the problem and potential solutions. Having paid positions for students would help attract students who are 
struggling and need money and hence might better relate to the students utilizing the food pantry.

Another university within the CSU system tackling food insecurity is California State University (Fresno State). There they have a centralized food pantry called "Fresno State Student Cupboard,” and from November 2014 to February 2016, there have been 27,827 visits of which 10,968 are new individuals (Fresno State Food Insecurity Project, 2017). A campus-wide survey was sent out to students at Fresno State indicating that $31 \%$ of students could not afford food, which is comparable to the numbers found at SJSU (Fresno State Food Insecurity Project About Us, 2017). Fresno State has a central location utilized exclusively for a food pantry. Furthermore, it has community partnerships with Fresno Community Food Bank in which the university is able to receive free and reduced cost food. Fresno State is an example of what it looks like to prioritize and, most importantly, invest in students. They invest at least $\$ 50,000$ each year that goes to various food recovery programs, trucks, and food, and ergo understand the importance of food as it relates to students' ability to learn effectively (Fresno State Food security Initiative Prospectus, 2015). SJSU needs to designate a facility on campus that can be utilized to run a centralized food pantry. Subsequently, it should enter into a contract with Santa Clara County Second Harvest Food Bank to provide food in order to address the problem comprehensively and efficiently. Without a centralized location, students are left out in open spaces, vulnerable and afraid to seek food that is available. Students may be wasting time traveling from one location to the next in search of the items they need and therefore feel stressed or guilty that they are taking food from 
someone in need. Without a partnership with a larger food bank, there is simply not enough food available to meet the need. Furthermore, many students are unaware that there are food resources available to them and are therefore left feeling alone and suffering silently. If a centralized food pantry were in place, it would help mitigate these problems. Students could have more conversation and share their own knowledge and experience regarding the food resources available.

Space is a highly sought-after resource on the campus of SJSU. There is no space available for a centralized food pantry, and any space that seems available has plans to be utilized by a department from campus planning six years ago. There is, however, plenty of space for privatized operations such as the new gym and aquatic center. Additionally, a new science building is going to be built across from Duncan Hall and the entire Associated Students House is going to be moved somewhere else to allow this development to proceed. Yet, somehow, a room cannot be found for a 250 sq. ft. centralized food pantry that would benefit approximately $33 \%$ of SJSU students.

\section{Fighting Stigma}

Food insecurity is still something that many college students are ashamed to admit they undergo. More time and energy can be spent reassuring students that they are not alone. Time could be spent encouraging students to get the resources they need now. Discussions could be centered around how the situation they are in now may not always be the case. Students could be reminded and applauded for doing their best to get their college degree and that it will help in seeking better employment opportunities. Students could be reminded of the importance of getting the food they need because food is 
essential to survive and thrive in an academic setting. It is unrealistic to be skipping meals or going entire days without eating or eating very little and still be academically successful. Not eating regularly can cause additional stress on top of learning, studying, taking exams, and daily functioning. The food resources we currently provide are helping a large number of students but only a fraction the 10,000 students that are in need. The university needs to provide quality, reliable resources proportionate to our student body. Coping with Stress

Many of the students who were food insecure experienced stress, which negatively impacted their mental health and well-being. In fact, according to the Annual Report released by the SJSU Counseling and Psychological Services (CAPS), stress was the number one reason students sought individual counseling at 66\% (1025 of 1562 students) of those who utilized CAPS from the year 2013-2014 (Lin 2014). The second reason for students seeking assistance from CAPS was for anxiety, as $64 \%$ of students indicated it was a top concern for them (Lin 2014). At SJSU, a third of the student body, approximately 11,000 students, experience food insecurity and, as aforementioned in the focus groups and interviews, many of these students are likely stressed. These students are likely to benefit from counseling services but currently CAPS would be unable to meet such a need.

The number of students seeking counseling has steadily been increasing each year. For the 2016-2017 academic year, 2,383 students at SJSU saw a personal counselor. The number of students attending SJSU is approximately 32,157 and has increased gradually over the years as well. Typically, across the nation, about ten percent of the student body 
population is served by personal counselors at colleges and universities. At SJSU, utilization of counseling services have gradually increased but a particular spike occurred 4-5 years ago due to more awareness through national prevention events and tragedies, which affected colleges and universities across the country. Currently, at SJSU there are 20 counselors, and of those, ten are clinical counselors, and this number has not changed greatly over the years. At the beginning of the semester, there is virtually no wait list, but this changes. The demand grows at the end of the semester, when there is low counselor availability or students have tight schedules. Those students able to see a personal counselor rate it as a highly effective service, averaging 4.6 out of 5 stars when it comes to helping them become better students, identify their problems, and resolve them (Lin 2014).

Counselors try to do the best they can to see as many students as possible or refer them elsewhere in the community. With 20 counselors, the ratio is less than one counselor per 1,000 students. The number of counselors at SJSU has not changed over the years. The counselors work together with various departments as a community to host events, extend outreach, and increase awareness among students, but they can only do so much. Considering the fact that such a significant portion of the student population at SJSU and other colleges and universities experience food insecurity, colleges and universities should move toward more funding for counseling. This funding should not come from student fees, as many students are struggling. It is unacceptable that more funding is not allocated to this department to assist students in critical need. The administration at SJSU is very supportive of CAPS and understands its importance, and 
yet, more funding is not dedicated to hiring additional counselors even though this program is highly utilized, sought after, and rated effective and beneficial among the majority of the students who use it.

The CCCAC runs the Associated Students Community Garden, the only garden on campus. The Community Garden provides SJSU students with the opportunity to volunteer at the garden and learn more about how to grow and pick fresh fruits and vegetables. Each time students visit, they can take fresh produce with them. This program was specifically designed with the intent of assisting students who are food insecure. The CCCAC is also considering selling some of its produce to Spartan Shops, which will help generate revenue, which has never been the goal of the Cesar Chavez Cesar Chavez Community Action Center. Proper support can come in several ways: 1) by understanding the value of an organization/department on a university campus other than generating revenue, 2) providing sufficient financial support, and 3) increasing a department's visibility within the university. It is important to note that a service responsible for serving thousands of students across the entire university is being run by such a small program, highlighting the university's practice of putting few resources toward programs that do not generate revenue.

\section{Community Garden}

The University needs to look to the A.S. Community Garden as a proof-of-concept it can then use to expand further and serve the greater population. If it were expanded, a campus-wide SJSU Community Garden could have tremendous benefits in terms of providing resources for students who are food insecure in fun, interactive ways. It could 
foster greater learning opportunities within numerous disciplines within the fields of Nutrition, Biology, Environmental Science, Engineering, and possibly others. In order for this garden to be successful, it needs campus-wide support and commitment. Yet, as a university more interested in short-term profit, it is willing to allow an underfunded and ineffective service to run because the costs to the University are minimal. Additionally, they are unwilling to invest in solving long-term problems that do not produce short-term profit, even though it would undoubtedly serve their students well and accomplish SJSU's stated mission. This example demonstrates how sectors that are not profitable and are resistant to commercialization are being pushed towards privatization and producing revenue.

Furthermore, the University has not made a financial commitment to securing food resources for students. Although it has led a few fundraisers and food drives relying on donations from their own staff and administration, it has not allocated a portion of the budget to this cause, which would potentially provide more consistent resources. SJSU needs to do more to take the lead with regards to combating food insecurity. Specifically, it needs to make a financial commitment. SJSU should follow the model and approach that CSU Fresno has taken, as they have been able to reach a substantial amount of their campus community. The question is not whether the money is there, but rather, is SJSU and its board of trustees willing to devise a budget that accurately reflects students' needs as priorities over any short-term profit? Can the University dedicate a space for a central food pantry to address student food insecurity? 


\section{FOOD RESOURCE LEGISLATIVE POLICIES ON COLLEGE CAMPUSES}

$A B 1747$

In response to the widespread presence of food insecurity among college students, there has been a series of legislation designed to assist colleges and universities in addressing this problem. Moving forward, college and universities should utilize the resources that are provided through this legislation to help their students suffering from food insecurity. On September 12th, 2016, Governor Jerry Brown signed into California Law Assembly Bill 1747, which was originally brought forth by California State Assembly member Shirley Weber. The purpose of AB 1747 is to increase the college graduation rates for low-income students by improving economic stability and decreasing food insecurity. AB 1747 stipulates that if colleges and universities want to continue receiving Cal Grant funding, they must comply with the following: 1) allow EBT transactions to occur without a surcharge, 2) spread more awareness and access to CalFresh Restaurant Meal Programs ${ }^{14}$, and 3) not enter into a contract with a bank/financial institution that charges EBT users. AB 1747 specifies that contracts entered or renewed after January 1st, 2017 must abide by these provisions. The bill also delineates that 1) on-campus food vendors are responsible for the creation of an EBT system, not the public colleges; 2) matching funds are provided by the USDA for public colleges and universities able to raise money for CalFresh outreach efforts; and 3) the

\footnotetext{
${ }^{14}$ CalFresh Restaurant Meal Programs allow people who are homeless, disabled, and above the age of 60 to utilize CalFresh/EBT benefits at participating restaurants to receive hot and prepared meals. This program takes into consideration that it may be difficult preparing a meal for members of these designated groups.
} 
Public Higher Education Pantry Assistance Program is formed. The Public Higher Education Pantry Assistance Program would provide funding to food banks so long as they directly serve low-income individuals and families and there is a specific cost associated with the on-campus food pantry that serves low-income college students. Overall, this bill is centered on making CalFresh more accessible to students and thereby utilizes public state resources to support public post-secondary higher education institutions. This bill also assists colleges and universities with funding that would go to a local food bank that serves low-income families and individuals to establish an on campus food pantry serving the student population. This bill is an example of funding from the state being used to benefit the public rather than private interest.

$A B 214$

On March 14th, 2017 AB 214 (another bill proposed by California State Assembly member Shirley Weber) was passed. The purpose of AB 214 is to provide a written notice to students who both receive $\mathrm{Cal}$ Grants and are eligible to receive CalFresh/EBT benefits. Additionally, students who are a part of other groups ${ }^{15}$ such as the Equal Opportunity Program, College Disabled Students Programs and Services and the McNair

\footnotetext{
15 a) The Educational Opportunity Program (EOP); b) College Disabled Students Programs and Services (DSPS); c) Cooperative Agencies Resources for Education (CARE); d) The McNair Scholars programs of the UC; e) The Puente Project of the California Community Colleges (CCC) Chancellor's Office and the UC; f) The Mathematics, Engineering, Science Achievement (MESA) programs of the CCC; g) The Guardian Scholar programs of the UC, the CSU, and the CCC; h) The Foster Youth Success Initiative (FYSI) of the CCC Chancellor's Office; i) The Cooperating Agencies Foster Youth Educational Support (CAFYES) Program established by Section 79220 of the Education Code; j) The Chafee Education and Training Voucher Program of CSAC; and, k) Any program or curriculum supported by the California Fostering Connections to Success Act.
} 
Scholars programs are also eligible to receive CalFresh benefits, even if they do not meet the requirements. CalFresh allows people to receive monthly benefits for food that can be utilized in grocery stores, farmers' markets, and restaurants if they are eligible for the Restaurant Meals Program. This bill is critical because many students may not realize what CalFresh is or that they are eligible to receive assistance. Efforts to combat stigma surrounding receiving food stamps from the government should be implemented so that students are not ashamed about signing up and receiving free food resources. $A B 453$

On May 31st, 2017, AB 453 was passed by California State Assembly member Monique Limon. AB 453 would provide colleges and universities with funding used specifically to assist low-income students by reducing their food insecurity. In order to receive these resources, colleges and universities in California would have to demonstrate the following: 1) a Swipe Out Hunger program that allows unused meals to be donated to students in need, 2) an on-campus food pantry or regular food distributions to students, and 3) a campus employee responsible for ensuring that students receive information about enrolling into CalFresh. Another component of this bill is that it is at the Legislature's discretion to determine whether a public post-secondary higher education institution qualifies for the status of a "hunger free campus" as well as the exact amount of funding they will receive. These provisions seem like excellent ways to gain food resources for students. However, they are not a $100 \%$ guarantee and may not necessarily eliminate hunger on a college campus, especially by January 1st, 2022, which is when the bill is repealed unless enacted by a statute. Therefore, during this time, copious research 
should be done on each college campus and university to keep track of whether and by how much food insecurity is being eliminated and to examine the programs, events, and processes that were most beneficial for students. These legislative policies demonstrate the State leading the charge in providing public funding to public higher education institutions.

However, the initiative surrounding this bill is problematic, as it creates competition between schools to receive the designation of a "hunger free campus." Colleges and universities part of the CSU system might be motivated to receive this label to avoid being the campus that does not have it instead of out of a genuine and committed concern to help students facing food insecurity be academically successful. Additionally, there is no guarantee that if a college indeed meets the three requirements of the bill, they will have successfully eliminated hunger at their institution or significantly reduced the number of students facing food insecurity. To act responsibly and ensure accountability, research should be conducted on all $23 \mathrm{CSU}$ campuses to monitor the effectiveness of the programs providing food resources and information. This research should be made public. Students should be involved in the development and oversight of this research to further assure that these institutions are complying with students' best interests. This research should be reviewed as frequently as possible in order to incorporate best practices that will benefit other CSU institutions. 


\section{DISCUSSION AND CONCLUSION}

The purpose of this research was to explore the food insecurity experiences of college students attending SJSU. Additionally, I have provided history and context regarding institutional programs and procedures for how food insecurity is dealt with at SJSU. One major take-away regarding students' experiences is that they feel tremendous shame when seeking help and resources. Another is that many of the students come from lowincome backgrounds, are the first in their family to attend college, and want to avoid being an additional burden to their family while pursuing their degree. Students are more likely to live in poverty if they are Black or Latino, first-generation, or raised by a single mother. Additionally, according to a study conducted by the Wisconsin HOPE Lab (2016) Students of Color contributed more financially to their family compared to White students. Additionally, students suggested that more awareness of the existing resources is needed. At SJSU, many resources and programs are being provided that students find extremely beneficial. However, more can be done to streamline these resources to take into consideration the busy lifestyle of many college students. For instance, it would be helpful to have food resources provided at multiple times and days of the week to take into account students' classes and work schedules. Also, by having a central food pantry, students do not have to worry about running across campus to find the resources they need, or worse, finding no resources and no one to assist them in finding further support. This research has demonstrated the ways in which privatization can negatively impact a college and university when it comes to fulfilling its mission and prioritizing student needs. 
This research is limited in terms of generalizability to both the campus community and other college students. Generalizability is a limitation often found when conducting qualitative research and dealing with a smaller sample size. Further qualitative and quantitative studies should be conducted to gain more insight into college students and their experiences with food insecurity. Additionally, through the interviews, I found other factors disproportionately affecting food insecurity such as 1) living in poverty, 2) being a first-generation college student, 3) being a student of color, 4) being raised by a single mother, and 5) being undocumented. However, information regarding whether or not students identified as LGBTQ was not included. The LGBTQ youth community is at an increased risk to experience poverty (Keuroghlian, Shtasel, and Bassuk 2014) and might be more susceptible to food insecurity, and additional studies taking this into consideration should be conducted. It is important to consider students as a whole having a variety of lived experiences impacting their lives. Students provide key information that should be focused on when developing program and policies surrounding food insecurity in higher education.

The CSU system has done a great job in galvanizing their campuses to add food pantries on their campuses. However, the work needs to continue to ensure that each school is living up to its mission by continuing to promote policies and programming that will lead to students being more academically successful (such as expanding Counseling and Psychological Services) because that is its institutional obligation and responsibility above profit. Caring about food insecurity should extend beyond colleges and universities taking traction to it because everyone else is doing it as a means to remain and 
competitive. Moreover, people should examine food insecurity on college campuses and wonder why much has not changed for people living in poverty and why intergenerational poverty exists? Feeding college students and young children is important but it just as equally as important to help feed their parents and grandparents and other members living in their family. No person alive today should be hungry. Access to nutritious and sufficient food is a right and denying it to those because they are viewed as undeserving or unimportant denies them their humanity and right to live a quality life. The work then continues to addressing root causes of food insecurity for all and most importantly working with the people most deeply affected by this issue. 


\section{BIBLIOGRAPHY}

Abramovitz, Mimi. 1999. Regulating the Lives of Women: Social Welfare Policy from Colonial Times to the Present. Boston, MA: South End Press.

Alcindor, Yamiche. 2017. "Trump Budget Cuts Programs for Poor While Sparing Many Older People." The New York Times, May 22.

Altbach, Philip G. and Daniel C. Levy. 2005. "Private Higher Education A Global Revolution." Global Perspectives on Higher Education 1-23.

Armaline, William, Glasberg, Davita Silfen, and Purkayastha, Bandana. 2015. The Human Rights Enterprise. Cambridge, UK: Polity Press.

Aronson, P. (2008). Breaking barriers or locked out? Class-based perceptions and experiences of post-secondary education. New Directions for Child and Adolescent Development 119(1):41-54.

Associated Students, SJSU, Board of Directors. 2016. "In Support of a Comprehensive Plan to address Food Insecurity among SJSU Students.” Retrieved on May 19, 2017 (file:///home/chronos/udb68793f60534ed6aae1d77a2cbfff2841a6af1b/Downloads/In\%20support $\% 20$ of $\%$ 20a $\% 20$ Comprehensive $\% 20$ Plan $\% 20$ to $\% 20$ address $\% 20$ Food $\% 20$ Insecuri ty\%20a mong\%20SJSU\%20Students\%20\%20signed42916754\%20(4).pdf).

Benmayor, Rina. 2002. "Narrating Cultural Citizenship: Oral Histories of First-GenECRTtion College Students of Mexican Origin.” Social Justice 29(4): 96-121.

Buckner, Elizabeth. 2017. "The Worldwide Growth of Private Higher Education: Cross-national Patterns of Higher Education Institution Foundings by Sector." Sociology of Education 90(4):293-314. 
Cabaniss, Emily R. and Jill E. Fuller. 2005. "Ethnicity, Race and Poverty Among Single Women: A Theoretical Synthesis." Race, Gender, and Class 12(2): 142162.

Cady, Clare L. 2014. "Food Insecurity as a Student Issue." Opinions and Perspectives 15(4): 265-271.

California State Department of Education. 1960. CA Master Plan for Higher Education in California: 1960-1975. Sacramento, CA. Retrieved on May 19, 2017 (http://www.lib.berkeley.edu/uchistory/archives_exhibits/masterplan/Mast erPlan1 960.pdf)

Cauthen, Nancy and Viany Orozco. 2009. "The High Cost of Working Hard: Why Students Need to Work Less and Study More." The American Prospect.

Christopher, Karren, England, Paula, Smeeding Timothy M., and Katherin Ross. "The Gender Gap in Poverty in Modern Nations: Single Motherhood, the Market, and the State." Sociological Perspectives 45(3): 219-242.

Counseling and Psychological Services.2014. "Student Food Access Survey."

Crutchfield, Rashida. 2016. "Serving Displaced and Food Insecure Students in the CSU." California State University, Long beach.

Covarrubias, Rebecca, Romero, Andrea, and Michael Trivelli. 2015. "Family Achievement Guilt and Mental Well-being of College Students." Journal of Child Family Studies 24(1): 2031-2037.

Dannenberg, Michael and Mamie Voight. 2013. "Doing away with Debt: Using Existing Resources to Ensure College Affordability for Low and MiddleIncome Families." Education Trust Retrieved on April 1, 2018 (http://https://files.eric.ed.gov/fulltext/ED543214.pdf).

Delaney, Jennifer A. 2014. "The Role of State Policy in Promoting College Affordability." The ANNALS of the American Academy of Political and Social Science 655(1): 56-78. 
Desmond, Matthew and Ruth N. Lopez Turley. 2009. "The Role of Familism in Explaining the Hispanic-White College Application Gap." Social Problems 56(2): 311-334.

Edin, Katherine and Joanna M. Reed. 2005. "Why Don't They Just Get Married? Barriers to Marriage among the Disadvantaged." Princeton University 15(2): 117137.

Edin, Katherine and Laura Lein. 1997. "Work, Welfare, and Single Mothers' Economic Survival Strategies.” American Sociological Association 62(2): 253-266.

Engle, Jennifer and Vincent Tinto. 2008. "Moving Beyond Access College Success For Low-Income, First-Generation Students." The Pell Institute: $1-30$.

Espiritu, Yen Le. 2006. "Toward a Critical Refugee Study: The Vietnamese Refugee Subject in US Scholarship.” University of California Press 1(12): 410-433.

Espiritu, Yen Le. 2006. “'We-Win-Even-When-We-Lose' Syndrome: U.S. Press CovECRTge of the Twenty-Fifth Anniversary of the 'Fail of Saigon."' American Quarterly 58(2): 329-352.

Federal Reserve Bank of New York. 2017. "Household Credit and Debt Report Q4 2017.” Retrieved on April 2, 2018 (http://https://www.newyorkfed.org/microeconomics/hhdc.html).

Feeding America. 2014. "Hunger in America Executive Summary." Feeding America: 1-28.

Feeding America. 2015. "Hunger and Poverty Facts and Statistics." Retrieved May 19, 2017 (http://www.feedingamerica.org/hunger-in-america/impactofhunger/hunger-and-poverty/hunger-and-povertyfactsheet.html?referrer=https://www.google.com/). 
Fox Piven, Frances and Richard, Cloward. 1993. Regulating the Poor: The Functions of Public Welfare. New York, NY: Vintage Books A Division of Random House, Inc.

Freudenberg N, Manzo L, Jones H, Kwan A, Tsui E, and Gagnon M. 2011. "Food Insecurity at CUNY: Results from a Survey of CUNY Undergraduate Students." Healthy CUNY Initiative, City University of New York (http://web.gc.cuny.edu/che/cunyfoodinsecurity.pdf).

Fresno State. 2017. "Food Security Project Student Affairs and Enrollment Management.” Retrieved May 19, 2017 (https://www.fresnostate.edu/studentaffairs/foodsecurity/studentcupboard.html)

Giroux, Henry A. 2010. "Bare Pedagogy and the Scourge of Neoliberalism: Rethinking Higher Education as a Democratic Public Sphere.” The Educational Forum 74(3):184-196.

Gold, Steve and Kibria, Nazli. 1993. "Vietnamese Refugees and Blocked Mobility." Asian Pacific Migration Journal 2(1): 27-56.

Gortmaker, Steven L. 1979. "Poverty and Infant Mortality in the United States." American Sociological Review 44(2): 280-297.

Higher Education Act of 1965. 1965. "Federal TRIO Programs Sec. 402A.20 U.S.C. 1070a-11." Retrieved on April 1, 2018 (http://https://www2.ed.gov/about/offices/list/ope/trio/triohea.pdf).

Holben, DH. 2010. "Position of the American Dietetic Association: Food Insecurity in the United States." Journal of the American Dietetic Association 110(9): 13681377.

Houle, Jason N. 2013. 'Disparities in Debt: Parents' Socioeconomic Resources and Young Adult Student Loan Debt." American Sociological Association 87(1): 53-69. 
Institute for Research on Poverty. 2016. "How is Poverty Measured in the United States?" Retrieved on April 2, 2018

(http://https://www.irp.wisc.edu/faqs/faq2.htm).

Johnson, Brian D. and Betsinger, Sara. 2009. "Punishing the 'Model Minority': Asian-American Criminal Sentencing Outcomes in Federal District Courts." Criminology 47(4): 1045-1090.

Keuroghlian, Alex S., Shtasel, Derri, and Bassuk, Ellen L. 2014. "Out on the Street: A Public Health and Policy Agenda for Lesbian, Gay, Bisexual, and Transgender Youth Who are Homeless." American Journal of Orthopsychiatry 84 (1): 66-72.

Klein, Naomi. 2014. This Changes Everything: Capitalism versus Climate Change. New York City, NY: Simon \& Schuster.

Levy, Daniel C. 2013. "The Decline of Private Higher Education.” Higher Education Policy 26(1): 25-42.

Levy, Daniel C. and William Zumeta. 2011. "Private Higher Education and Public Policy: A Global View." Journal of Comparative Policy Analysis: Research and Practice 13(4): 345-349.

Lin, Ellen J. 2014. “Counseling Services Annual Report 2013-2014.” Counseling and Psychological Services. Retrieved March 30, 2018.

(http://file:///home/chronos/udb68793f60534ed6aae1d77a2cbfff2841a6af 1b/Downloads/Counseling\%20Center \%20Annual\%20Report\%202013-2014.pdf)

Luhby, Tami. 2012. "Welfare Spending Cut in Half Since Reform.” CNN Money Retrieved on April 2, 2018 (http://http://money.cnn.com/2012/08/09/news/economy/welfarereform/inde x.htm).

Myers-Lipton, Scott. 2015. Ending Extreme Inequality. New York, NY: Paradigm Publishers.

National Academies Press. 2006. "Concepts and Definitions.” Pp. 41-54 in Food Insecurity and Hunger in the United States: An Assessment of the 
Measure, edited by G. S. Wunderlich and J. L. Norwood. Washington D.C. United States: The National Academies Press.

Neubeck, Kenneth J. and Noel A. Cazenave. 2001. Welfare Racism: Playing the Race Card Against America's Poor. New York, NY: Routledge.

Ngo, Bic. And Lee, Stacy J. 2007. "Complicating the Image of Model Minority Success: A Review of Southeast Asian American Education." American Educational Research Association 77(4): 415-453.

Ovetz, Robert. 1996. "Turning Resistance into Rebellion: Student Movements and the Entrepreneurialization of the Universities." Capital and Class 58113-152.

Powell, Farran. 2017. "Cost-Conscious Families Choosing In-State Colleges." U.S News, July 31.

Rainwater, Lee and Timothy M. Smeeding. 2003. "Doing Poorly: Child Poverty in Cross-National Context." Children, Youth, and Environments 13(2): 130.

Rondini, Ashley C. 2015. "Healing the Hidden Injuries of Class? Redemption Narratives, Aspirational Proxies, and Parents of Low-Income, FirstGeneration College Students.” Sociological Forum 31(1): 96-116.

Saltman, Kenneth J. 2006. "The Right-Wing Attack on Critical and Public Education in the United States: From Neoliberalism to Neoconservativism." Cultural Politics 2(3): 339-358.

San José State University Institutional Effectiveness and Analytics. December 2016. "Student Quick Facts." Retrieved on May 19, 2017 (http://www.iea.sjsu.edu/Students/QuickFacts/).

San José State University. 2016. "Mission.” Retrieved May 19, 2017 (http://www.sjsu.edu/about_sjsu/mission/).

Second Harvest Food Bank. 2014. "Hunger in Our Own Backyard." Second 
Harvest Food Bank. Retrieved on March 30, 2018.

(http://file:///home/chronos/udb68793f60534ed6aae1d77a2cbfff2841a6af1b/

Downloads/HungerStudy2014.pdf)

Sheinin, Richard. 2017. "It's a fact: The Bay Area Rental Market has softened." The Mercury News. Retrieved on May 19, 2017

(http://www.mercurynews.com/2017/01/03/its-a-fact-the-bay-area-rentalmarkethas-softened/).

Spring, Joel H. 1972. Education and the Rise of the Corporate State. Boston, MA: Beacon Press.

SJSU's Four Pillars of Student Success: College Readiness, Advising, Student Engagement and Clearing Bottlenecks Retrieved on May 5, 2016 (http://www.sjsu.edu/provost/docs/Student_Success_Plan_5-5-16.pdf).

Swartz, Amy E. and Benjamin Scafidi. 2003. "What's Happened to the Price of College? Quality-Adjusted Net Price Indexes for Four-Year Colleges." Journal of Human Resources 39(3): 723-745.

Takei, Isao and Arthur Sakamoto. 2011. "Poverty among Asian Americans in the 21st Century." Sociological Perspectives 54(2): 251-276.

The American Presidency Project. "Ronald Regan Inaugural Address January 20, 1981." Retrieved on April 2, 2018 (http://http://www.presidency.ucsb.edu/ws/?pid=43130).

The California State University. 2016. "The Mission of the California State University." Retrieved May 19, 2017 (http://www.calstate.edu/explore/missions.shtml).

The National Center for Public Policy and Higher Education. 2011. "Affordability Transfer: Critical to Increasing Baccalaureate Degree Completion." Retrieved on April 1, 2018 (http://http://www.highereducation.org/reports/pa_at/index.shtml).

Torche, Florencia. 2005. "Privatization Reform and Inequality of Educational Opportunity: The Case of Chile." Sociology of Education 78(1): 316-343. 
Twil, Sarah E., Bergdahl, Jacqueline, and Rebecca Fensler. 2016. "Partnering to Build a Pantry: A University Campus Responds to Student Food Insecurity." Journal of Poverty 20(3): 340-358.

Um, Khatharya. 2003. "A Dream Denied: Personal Experiences of Southeast Asian American Youth Issues and Recommendations." University of California Berkeley.

United States Department of Education. April 2016. "Developing HispanicServing Institutions Program - Title V." Retrieved on May 19, 2017 (https://www2.ed.gov/programs/idueshsi/definition.html).

United States Department of Agriculture Economic Research Service. 2017.

"Measurement." Retrieved on March 31, 2018.

(http://https://www.ers.usda.gov/topics/food-nutrition-assistance/foodsecurity-inthe-us/measurement.aspx).

Vice President for Student Affairs Office. December 2016. "Supporting our Students:

ECRT, Just In Time and CalFresh Sign-Ups!” Retrieved on May 19, 2017 (http://www.sjsu.edu/studentaffairs/newsletter/2016Newsletters/issue4/vpoffice /index.html\#college).

Waldman, Paul. 2017. "Happy Hour Roundup.” The Washington Post, September 21.

Wang, Tiffany R. 2014. "'I'm the Only Person From Where I'm From to Go to College': Understanding the Memorable Messages First-Generation College Students Receive From Parents." Journal of Family Communication 14(3): 270-290.

Wellman JV. The Secretary of Education's Commission on the Future of Higher Education. "A national Dialogue: The Secretary of Education's Commission on the Future of Higher Education." Retrieved on April 1, 2018 (http://https://www2.ed.gov/about/bdscomm/list/hiedfuture/reports/wellm an.pdf). 
Wheeler, Melissa. 2016. "Potential Family and Mental Health Considerations for Working with First Generation College Students Exploring Careers." Career Planning and Adult Development Journal 112-119.

Zalaquett, C. P. (2005). "Study of Successful Latino/a Students." Journal of Higher Education 5(1): 35-47. 
Appendix A

Figure 1. Silicon Valley University Demographics

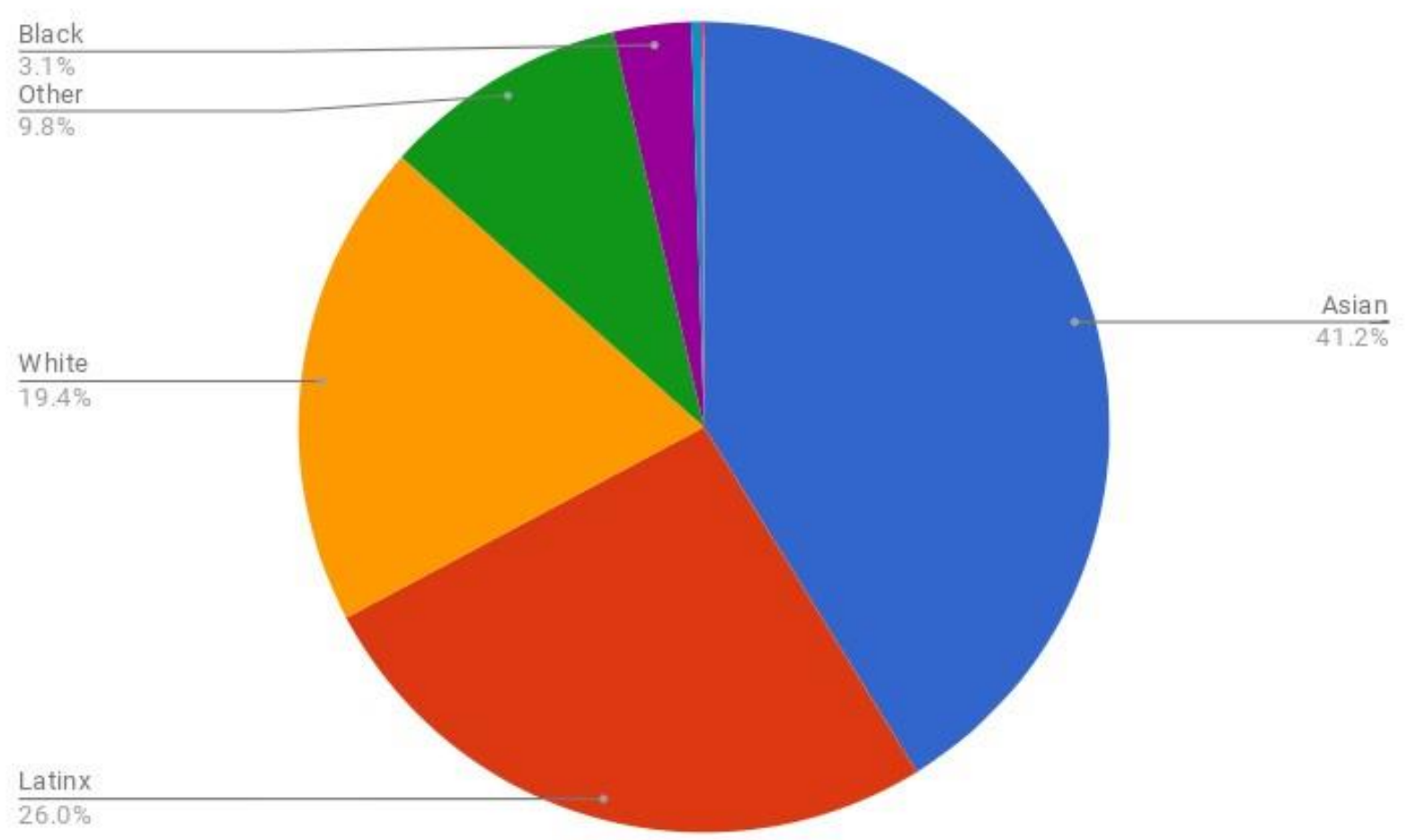


Appendix B

\section{College Students' Experiences with Food Insecurity}

My name is Elizabeth Agramont-Justiniano. I am a graduate student of Sociology at San José State University.

I am conducting a research project entitled: “College Students' Experiences with Food Insecurity".

This research focuses on how college students define, experience, and manage food insecurity and how it relates to their perceptions of health and illness. I am studying how students deal with food insecurity while attending college and what role it plays in their lives.

I would like to interview you in a focus group of approximately 5 students about your experience as a college student experiencing food insecurity.

The focus group should last no more than 2.5 hours.

In appreciation of your time and participation, I will be giving you a $\$ 20.00 \mathrm{gift}$ card to a major grocery retailer. You should know that this token of appreciation does NOT make you obligated to answer any questions you may be uncomfortable asking and you should also know you may end the focus group interview at any time and for any reason.

If you would like to participate in this study, please email me at: elizabeth.agramontjustiniano@sjsu.edu

Thank You!

Elizabeth 


\section{Appendix C}

SJSU 15 Food Shelf Locations ${ }^{16}$ :

1. Associated Students General Services

2. Peer Connections

3. Student Wellness Center

4.Counseling and Psychological Services (CAPS)

5. MLK Library 4th Floor (Student Computer Center will be rolled out on bookshelf around $6 \mathrm{pm})$.

6. ACCESS Center

7. Associated Students House

8. School of Social Work

9. Business Success Center, Jack Holland

10. Child Development Center

11. International Gateways

12. Office of International Student and Scholar Services (ISSS)

13. Career Center

14. Student Housing

15. College of Science Advising Center (COSAC)

${ }^{16}$ SJSU had 15 Food Shelf locations in May 2016 but has since lowered the number to 7. 